\title{
Phytoremediation and Bioremediation of Pesticide-Contaminated Soil
}

\author{
Divine N. Tarla ${ }^{1,2}$, Larry E. Erickson ${ }^{1, *(D)}$, Ganga M. Hettiarachchi ${ }^{3}\left(\mathbb{D}\right.$, Sixtus I. Amadi ${ }^{4}$, \\ Madhubhashini Galkaduwa ${ }^{3}$, Lawrence C. Davis ${ }^{5}$, Asil Nurzhanova ${ }^{6}$ and \\ Valentina Pidlisnyuk ${ }^{7}$ \\ 1 Department of Chemical Engineering, Kansas State University, Manhattan, KS 66506, USA; tarladn@yahoo.fr \\ 2 Department of Plant Protection, Faculty of Agronomy and Agricultural Sciences, University of Dschang, \\ Dschang B.P. 96, Cameroon \\ 3 Department of Agronomy, Kansas State University, Manhattan, KS 66506, USA; ganga@ksu.edu (G.M.H.); \\ buddhika@k-state.edu (M.G.) \\ 4 Hydrochrom Resources Limited, Lagos, Nigeria; sixtus@hydrochrom.com \\ 5 Department of Biochemistry and Molecular Biophysics, Kansas State University, Manhattan, KS 66506, USA; \\ ldavis@ksu.edu \\ 6 Institute of Plant Biology and Biotechnology, Almaty 050040, Kazakhstan; gen_asil@mail.ru \\ 7 Department of Environmental Chemistry and Technology, Jan Evangelista Purkyne University, \\ 40096 Usti nad Labem, Czech Republic; pidlisnyuk@gmail.com \\ * Correspondence: lerick@ksu.edu; Tel.: +1-785-532-4313; Fax: +1-785-532-7372
}

Received: 2 December 2019; Accepted: 30 January 2020; Published: 11 February 2020

\begin{abstract}
Management and destruction of obsolete pesticides and the remediation of pesticide-contaminated soil are significant global issues with importance in agriculture, environmental health and quality of life. Pesticide use and management have a history of problems because of insufficient knowledge of proper planning, storage, and use. This manuscript reviews recent literature with an emphasis on the management of obsolete pesticides and remediation of pesticide-contaminated soil. The rhizosphere of plants is a zone of active remediation. Plants also take up contaminated water and remove pesticides from soil. The beneficial effects of growing plants in pesticide-contaminated soil include pesticide transformation by both plant and microbial enzymes. This review addresses recent advances in the remediation of pesticide-contaminated soil with an emphasis on processes that are simple and can be applied widely in any country.
\end{abstract}

Keywords: pesticide; phytoremediation; soil; persistent; rhizosphere; obsolete

\section{Introduction}

The production and application of pesticides has a long history because of the many benefits associated with their use. There is a huge literature related to biodegradation of pesticides, microorganisms that degrade pesticides, bioremediation and phytoremediation of pesticide-contaminated soils, and soil amendments for pesticide remediation [1-305]. This review addresses recent advances in the remediation of pesticide-contaminated soil with an emphasis on processes that are simple and can be applied widely in any country. An attempt is made to include methods, content and literature that will be valuable to professionals in developing countries who are addressing pesticide remediation and management of pesticide-contaminated soils. Bioremediation and phytoremediation are inexpensive and can be implemented in many locations, and this manuscript has a focus on these remediation methods. In many locations, crops like vegetables need pesticides because of significant yield losses without pest control [82,149]. Pesticides have enhanced food production to meet the needs of a growing population $[17,18,46,82,105,119,129,220,247]$. 
However, large scale application of pesticides has often had a negative impact on human health and the environment $[2,3,5,9,30,33,36,39,51,55,67,109,123,131,132,135,140,143,145,150,153,167,192,194,196$, 207,212,215,229,230,257,258,263].

The Peoples Republic of China, United States of America, Argentina, Thailand, and Brazil are the top five countries in pesticide use [16]. The use of pesticides in Africa has reportedly increased from 2055 to 4000 tons of active ingredients from 2004 to 2011 on a per country basis [68] but the data is of uncertain quality. Cameroon is a medium consumer of pesticides in Africa compared to higher consumers like Ghana and Mauritius and lower consumers such as Mozambique [194].

\section{Types of Pesticides}

Pesticides may be grouped according to the pest to be controlled (algicides, bactericides, fungicides, herbicides, insecticides, nematicides, and rodenticides) [34,234]. Chemical classes of organic pesticides include organochlorine, organophosphorus, acetamides, carbamates, triazoles and triazines, neonicotinoids and pyrethroids [179]. This review does not address inorganic pesticides including lead arsenate, chromated copper arsenate, copper acetoarsenite (Paris Green), Bordeaux mix (copper sulfate + calcium oxide), borax and boric acid complexes. The dithiocarbamate compexes Zineb (Dithane) and maneb, contain zinc or manganese, respectively. Removal of inorganic elements from soils requires different technologies than for organics $[8,57,104,110,113,136,195,259]$.

One important group of pesticides are those that have been included on the list of persistent organic pollutants (POPs). Fourteen organochlorine compounds such as DDT (dichlorodiphenyltrichloroethane), chlordane, heptachlor, and toxaphene are included in the POP list $[238,239]$. These pesticides are persistent in the environment and have a high octanol/water partition coefficient which causes them to bioconcentrate in the lipid-rich tissue of organisms $[2,67,90,95,167]$. Some may cause cancer $[170,197]$. Some volatile POPs are transported through the air to locations where they pollute environments where they have not been applied $[138,269]$. Because of health and environmental issues, many organochlorine pesticides are no longer approved for use in many parts of the world $[238,239,245]$. There is still some approved use of DDT in some parts of Africa and India because of malaria [51,247,270].

The chemical and physical properties of pesticides are important because they impact the application process, effectiveness, and potential for in situ remediation. These include chemical composition, chemical structure, volatility (melting temperature, boiling point, vapor pressure, Henry's constant), half-life in the application environment, octanol/water partition coefficient (Kow), soil adsorption coefficient $(\mathrm{Kd})$, and diffusivity in both air and water. Many values may be found in the published literature for many pesticides [40,102,132,141,144,277,291].

\section{Obsolete Pesticides}

There are significant quantities of obsolete (out-dated, or banned) pesticides in many countries. These pesticides need to be processed to reduce their toxicity because they are no longer useful or legal to use $[16,24,42,52,61,65,69,73-75,101,138,161,170,173,177,209,231,235,260]$. For example, Tarla and coworkers reported finding 210,047 kg and 309,521 L of obsolete pesticides in Cameroon. This included $4146 \mathrm{~kg}$ of POPs [231]. The risk assessment identified 195 sites with contamination [231]. In Kazakhstan 354.7 tons of pesticides were reported in 26 stockpiles [169,174]. In Ukraine, more than 3000 pesticide storage sites and 2000 polluted soil sites have been reported [156,157]. There has been some progress in transporting some of the hexachlorobenzene from a factory in Ukraine to Poland and Germany where it has been incinerated [140]. In some African countries obsolete pesticides have been collected and destroyed as part of the Asian Stockpiles Program [14,146,271]. There are reports of obsolete pesticides in Russia, former Soviet Union countries, Central and Eastern Europe, Asia, and the Middle East $[6,55,61,70,91,94,117,134,170,246,252,261,271]$. The Food and Agriculture Organization (FAO) has provided leadership and financial support for some of the efforts to address obsolete pesticide problems [271]. FAO estimates that the quantity of obsolete and unwanted pesticides is about 
500,000 tonnes. About $10 \%$ of this is in Africa, and about $40 \%$ may be in the 12 former Soviet Union Republics [271]. While there has been significant progress in the incineration of obsolete pesticides, a significant portion of the 500,000 tonnes has not been destroyed as of 2019 .

Incineration of pesticides at high temperature has become the method of choice to destroy obsolete pesticides [271-273] although this approach also has some disadvantages such as generating toxic emissions and ash that may contain potentially hazardous substances. Incinerators designed for thermal processing of pesticides and cement kilns that produce cement while burning pesticides as a fuel have been successfully used [271-273]. Sometimes a mixture of fuels is burned in order to achieve the desired results.

Risk assessment and risk management are important in working with pesticides because spills in storage sheds and onto soil may present risks for those who remediate the site $[7,58,126,271]$. Education of those who work with pesticides as well as the general public must be a high priority in order to implement health and safety programs that are designed to protect workers and the public [271,272].

There are many locations in the world where pesticides have been put into storage sheds that need to be cleaned up because the site is no longer needed for storage and the pesticides that are present at the site can no longer be applied for their intended purpose. There are safety concerns at some of these sites because of leaking containers and spills. In many cases there is soil contamination at storage sites and surrounding areas because pesticides have been spilled and dispersed [169,173,174].

\section{Analysis of Pesticides to Monitor Clean-Up}

Successful clean-up of obsolete pesticides requires sensitive analytical methods to monitor and verify that the clean-up process is working. There is significant literature on analytical methods to determine concentrations of pesticides in soil, water and foods [11,106,168,213,234,240,241]. This includes the US Environmental Protection Agency (EPA) Internet site under the heading Environmental Chemistry Methods [241], and AOAC International online and printed products [11]. Methods for organic pesticides include gas chromatography (GC), high-performance liquid chromatography (HPLC) [19,127], thin-layer chromatography (TLC) [96], spectrophotometry [120], polarography [208]. With GC, electron capture (ECD), nitrogen phosphorus (NPD), and flame photometric (FPD) detectors and mass spectrometry (GC-MS) have been used [56,77,142,203,213,248]. Liquid chromatography has been used with mass spectrometry (LC-MS) [213,240].

Sample preparation methods are an important part of chemical analysis of pesticides in soil and plants [11,241]. Numerous methods have been developed and used for the separation of pesticides from soil and plant matter. Liquid extraction processes have been used extensively for sample preparation [63,77,250]. Sonication has been used to enhance mixing and extraction effectiveness [77]. Solids are often present when pesticides are associated with plants or soils, and the extraction process may include extraction from a solid phase. Furthermore, many pesticides have much higher concentrations in fat and lipids. Determining the concentration of a pesticide is difficult if part of the pesticide is distributed in lipid-rich regions. In the analysis of pesticides, solid-phase extraction [11], solid-phase microextraction (SPME) [213], microwave-assisted extraction [108], and supercritical fluid extraction [203] have been used. There is a quick, easy, cheap, effective, rugged, and safe (QuEChRS) method for the preparation of pesticide samples [240].

Solid-phase extraction of samples from soil followed by chemical analysis using GC-MS has been reported for 103 pesticides including organochlorines, carbamates, organophosphates, and pyrethroid compounds [186]. EPA Method 508 has been used for analysis of chlorinated pesticides in water [241]. EPA Methods 508.1, 525.2, 527, 8081 B, and 8151 A have been used for pesticide analysis [241,242]. There are many reports with applications of chemical analysis methods and results at specific sites $[19,56,107,125,186,203,213,240,248]$. Silva et al. have used liquid chromatography tandem mass spectrometry (LC-MS/MS) and gas chromatography-high-resolution mass spectrometry (GC-HRMS) [282]. 


\section{Soils Contaminated with Pesticides}

Good productive soil has a vital role in agriculture, and it is a key component of terrestrial ecosystems. Pesticide-contaminated soil is a global concern because of spills, cleaning of spray equipment and empty containers, and land-use changes from agriculture to residential living. Erosion and flood waters may move pesticides from both treated land and storage sites to soils down-gradient and in the flood plain. Where high concentrations of active ingredients are released, both plants and microorganisms may be killed. There may be health risks when animals and people come to contaminated sites because of toxicity to non-target organisms $[41,48,66,67,118,161,170]$. Inappropriate pesticides may be taken up into garden vegetables and fruit. Pesticides in soil may contaminate ground water that is used as drinking water. Pesticides in soil from prior use may affect the fate of, or contaminate a different crop that is planted.

Silva et al. have reported results for 76 pesticide residues in topsoil for 11 European countries for 6 cropping systems. Many soils had more than one pesticide present; the maximum total pesticide concentration reported was $2.87 \mathrm{mg} / \mathrm{kg}$ [282]. Detection levels were $0.05 \mathrm{mg} / \mathrm{kg}$ for glyphosate, $0.01 \mathrm{mg} / \mathrm{kg}$ for LC-MS/MS detection, and $0.005 \mathrm{mg} / \mathrm{kg}$ for GC-HRMS detection [282]. No pesticide residues were reported in $17 \%$ of the fields. A single pesticide was identified in $25 \%$ of the fields, while more than one pesticide residue was found in $58 \%$ of the sites [282].

Yadav et al. have reviewed the literature on organochlorine pesticides in soil and reported values for 4 cities in Nepal [293]. A range of values is reported for data from China, India, Mexico, Uganda, Kenya, Pakistan, Central Europe, and Nepal for DDT, hexachlorocyclohexane, and endosulfans [293]. The largest value reported is $2.179 \mathrm{mg} / \mathrm{kg}=2179 \mathrm{ng} / \mathrm{g}$ for DDT and metabolites of DDT [293]. Most values for DDT and its metabolites are greater than $0.1 \mathrm{ng} / \mathrm{g}$ and smaller than $100 \mathrm{ng} / \mathrm{g}$ [293]. The values reported by Zhang et al. for China are in a similar range [294].

Historically, excess or obsolete pesticides were buried in trenches, placed in dumps, or deposited in unlined landfills in many countries $[30,84,246]$. Disposing of pesticides in burial sites and landfills is not recommended in most countries, because of the risk of contaminating ground water. Remediation processes have been implemented to remove, contain, or degrade buried pesticides at a number of sites [84]. Monitoring of concentrations in ground water near landfills and pesticide burial sites has enabled communities to be informed of contamination issues and take appropriate action. It is important to collect information on burial sites and locations where ground water is contaminated in order to inform the public and prevent exposure to pesticide contaminants. Information on locations and contents of burial sites can help prevent using these sites for new construction $[117,246]$.

\section{Pesticides and Soil Ecology}

One aspect of soil ecology is biodiversity of soil fauna. In healthy soils there are bacteria, fungi, protozoa, nematodes, arthropods, and earthworms. Bacteria and fungi are important for biodegradation of pesticides and other organic matter $[59,114,191,199,200]$. Arbuscular mycorrhizal fungi are associated with plant roots and rhizodegradation, and they improve ecological health $[115,218]$. Symbiotic fungi are beneficial for plants in contaminated soil, and they have a positive impact on pesticide degradation in the rhizosphere [116,187]. Mycorrhizal colonization of roots results in an increase of root surface area and enhances nutrient acquisition for plants [218,295]. Microbial endophytes protect plants and contribute to plant tolerance to herbicides [232] while rhizosphere-associated bacterial populations enhance pesticide degradation [references cited in 122, 133, 305]. Nematodes, arthropods, and earthworms are beneficial in soil as indicator organisms, organic matter degraders, and soil structure modifiers [49,93]. The populations of these organisms are negatively affected by some pesticides $[41,62,93]$.

Before pesticides are released on the market, thorough testing of their active ingredients' ecotoxicological effects must be performed to evaluate whether the risk is at an acceptable level [300,304]. However, numerous studies are reporting the toxicity of pesticides on soil ecosystems $[41,48,100]$. These effects fall into three general categories: inhibition of microbial functions, reduction of microbial group abundance, changes in the composition and diversity of soil microbial communities. Reviews 
by Lo [298] and Puglisi [301] provide a general overview of the response of soil microorganisms to pesticides. It should be noted that Puglisi concluded that the usage of the recommended dosage and other good agricultural practices would help to minimize their detrimental effects on microorganisms and suggested further promoting policies focused on implementation of these practices. Researchers, as well as organizations such as European Food Safety Authority (EFSA), recently pointed out the need for new tests to better evaluate the impact of pesticides on soil microbial communities as well as overall soil quality [302,303].

Numerous studies focus on the effects of pesticides on specific groups of soil biota [76,93]. For instance, the effects of pesticides on earthworms have been reviewed recently [296]. Damage to DNA, changes in enzyme activity and altered membrane stability have been reported. For earthworms, the most harmful families of pesticides are carbamates, nicotinoids, organophosphates, strobilurins, sulfonylureas, and triazoles [296]. Earthworm, nematode, and protozoa populations may be reduced by application of herbicides [297]. Zaller et al. [299] cite half a dozen examples of major non-target impacts on flora and soil fauna from a range of common pesticides.

Microbial biomass in soils is a good measure of soil quality [297]. Lo has reviewed the literature on the effects of 21 pesticides on soil microorganisms, and concluded that it is difficult to predict organism responses from knowledge of pesticide chemistry [298]. Beneficial microbial communities are important in crop production but their effectiveness can be reduced by pesticide application [297-299] . Mycorrhizal fungi associated with roots are negatively affected by application of fungicides; in situ activity of enzymes such as dehydrogenases which are linked with microbial respiratory processes, may be affected by pesticide applications, and there may be interactive effects on soil biota when more than one pesticide is applied [299].

\section{Remediation of Pesticides}

The remediation of pesticides in soil and ground water is important because of public health, the need for healthy productive soils, and for drinking water that is safe to consume. There are several reviews of research on the remediation processes for pesticide contaminated soil $[4,13,21,34,40,78,111,114,122,147,163,192,200,214,219,222,223,228,236,262,274-281,283,284]$. The review on physicochemical remediation processes [275] is a very recent addition to the literature, and the review on bioaugmentation [277] was published in 2017. These two reviews have good content on the specific topics that are reviewed. Cycon et al. [277] have a table of physico-chemical properties of selected pesticides and a table of characteristics of the degradative potential of pesticide-degrading microorganisms for selected pesticides. Remediation using Fenton reagent has been identified as an effective physicochemical process by Baldissarelli et al. [275]. Rodrigo et al. [278] have provided a very good review on electrochemically assisted remediation of pesticides. Rodrigo et al. review the electro-Fenton process, in which the hydrogen peroxide is produced electrochemically in situ. One of the positive results of the oxidation of pesticides with the Fenton process is the completion of the oxidation such that there are few toxic intermediates in the processed product. The Fenton process is very appropriate for treating wastewater containing pesticides. It can be used to treat rinse water from pesticide containers and spraying equipment. Oturan and coworkers have reviewed the degradation of pesticides in water using the electro-Fenton process [281].

The present review will focus on biological remediation processes including phytoremediation. These processes are appropriate for application in all countries because they are cost-effective and relatively simple to implement. Bioremediation can take place under aerobic and anaerobic conditions $[25,111,133,221]$. The science of bioremediation is important for both in situ bioremediation and in applications where pesticide-contaminated soil is treated using composting, land farming or biopiles [34,111,264,277,279,283,284].

Eevers and coworkers have developed tables that report information on the microorganism, the pesticide that it degrades, the environment where the organism was found, and the published reference for bacteria and fungi [283]. Hussain et al. have developed tables for commonly used 
pesticides with listings of microorganisms that degrade the pesticide and the corresponding references where further information is available [111]. In addition there is a table with information on the genes and enzymes that are involved in detoxification of each pesticide [111].

Genetic engineering research has been conducted to develop microorganisms that are effective for the biodegradation of pesticides and pesticide residues $[47,60,179,205,287]$. Hussain and coworkers have reviewed research progress on this topic [111]. Recently, Huang et al. [285] have reviewed microbial degradation of pesticide residues by both natural and recombinant microorganisms. This paper includes a table with names of microorganisms and a listing of the pesticides that they degrade [285]. Liu et al. have reviewed recent progress with genetically engineered organisms that have been prepared to improve biodegradation of pesticides [286]. Table 1 in Reference 236 provides a stepwise process to develop genetic capability, which includes identification of the genetic ability, evaluation of the capability, modification to improve effectiveness, reevaluation of the improved microorganism, development of detection methods to evaluate effectiveness if needed, and application of the newly developed microorganism [286]. The advantages of recombinant methods in developing better microorganisms for biodegradation are reviewed, and a table listing important genes and host microorganisms for pesticide biodegradation is provided [286].

Bioaugmentation is known to be beneficial in many applications; however, there are a number of actions to consider that may be helpful. The moisture content, $\mathrm{pH}$, temperature, organic matter content (nutrients), pesticide concentration, and inoculum concentration are important. The recommended quantity of cells for bioaugmentation is of the order of a million to a billion organisms per $\mathrm{g}$ of soil. In some cases repetition of bioaugmentation has been beneficial. Immobilization of cells on supports has been reported to improve the effectiveness of bioaugmentation [277]. The food and nutrition for the organisms is important. It needs to be considered because at low concentration the pesticide may not supply sufficient $\mathrm{C}$ or $\mathrm{N}$ to support growth. At high concentrations, the pesticide may be toxic. Cycon et al. [277] have reviewed research on bioaugmentation for pesticide-contaminated soil for a number of microorganisms and for a number of pesticides. They have prepared a table that includes the effective organism, the pesticide, inoculum size, and the references.

\subsection{Composting}

Composting of wastes is a simple process that can be implemented easily in all parts of the world. Yanez-Ocampo et al. have reviewed the composting of pesticides in soils and provide a listing of microorganisms that degrade selected pesticides [264]. One concern with composting of pesticides is the extent of degradation of the pesticide during composting [32,34,158,216,243,264]. The toxicity of the product after composting should be evaluated. When pesticides in soil are composted by adding manure and other wastes to the soil, there is some beneficial dilution. It is important to add microorganisms that can biodegrade the pesticide. Soil from a field where the pesticide has been used regularly may have effective microorganisms. Leaves, manure, yard trimmings, straw, corn stalks, food wastes, and biosolids from wastewater treatment are examples of materials to add to a composting process to provide food for the organisms. Complete mineralization of pesticides should not be expected in composting of pesticides $[32,35,216]$. Reports on composting in biobeds in Europe $[80,81,121]$ and Africa [92] are available.

\subsection{Land Farming}

Land farming of soils containing pesticides involves spreading the solids over a land area that is designed for bioremediation of the pesticide [34,103]. Land farming of pesticides has been reported in Mali $[98,99]$ under conditions where plants were established to enhance the remediation. The spreading of the contaminants over a large area dilutes the pesticides. Biodegradation is the desired result, but there may also be loss by volatilization. This method is appropriate for pesticides that are well known to be biodegradable. It should not be used for persistent pesticides. 


\subsection{In Situ Bioremediation and Phytoremediation}

There has been significant progress in developing in situ bioremediation for pesticides [25,86-88,92,111,112,134,151,154,159,162,180-182,185,188,202,204,206,244,277,283,284,286]. These methods fall into three general categories; phytoremediation, bioremediation by indigenous organisms and bioaugmentation. Vegetation has been beneficial in the bioremediation of pesticides in many locations for many different pesticides $[1,22,26,38,44,45,50,54,79-81,83,85,111,122,147,148,152$, $171,175,176,180,221,244,253,283,284]$. With vegetation present in the contaminated soil, degradation of the pesticide near the roots is supported by substrates coming from the roots that enhance microbial growth and the magnitude of the active microbial population $[22,187,207]$. Bacteria and fungi in the root zone provide beneficial genes and play important roles in the biodegradation of pesticides [206,218]. Some pesticides are taken up into the plant and transformed by plant enzymes. The octanol/water partition coefficient of the pesticide is important in phytoremediation because it affects the solubility of the pesticide in water, the uptake into plants, and the distribution of the pesticide in the soil and in the plant $[13,124,180,193,256]$; see Paschke et al. for values of the octanol/water partition coefficient for pesticides [291]. Biodegradation of pesticides by endophytic bacteria associated with plants is important in many biodegradation processes. Listings of plants that take up pesticides and the pesticides that have been reported to be transformed by plant enzymes are available $[111,152,283]$. The process of establishing vegetation and nurturing growth is inexpensive compared to many of the other remediation processes. It can be applied at field scale $[88,113,160,164,165,184,210]$. The vegetation reduces wind-blown dust and the movement of the pesticides from the site [156]. Nurzhanova et al. $[169,173,174]$ have provided a list of 17 pesticide-tolerant plants that grew in soils where high pesticide concentrations were present. The growth of plants in contaminated field soil often improves soil quality by increasing microbial populations and organism diversity, and by adding organic matter to the soil $[10,26,53,189,190]$. The common results after phytoremediation of contaminated soil are that pesticide concentrations in soil are reduced and pesticide concentrations in roots are less than the concentrations in the soil, but larger than the concentrations in the stems and leaves of the plants $[4,156]$.

There have been several efforts to develop transgenic plants for phytoremediation of pesticide-contaminated soils [284]. The process that plants use may involve 1) addition of a reactive group such as $\mathrm{OH}$ to the pesticide, 2) conjugation of another compound to the pesticide through reaction with the reactive group, and 3) integration of the conjugated pesticide into cell-wall components or another part of the plant where the new substance is less toxic [236,283,284]. Atrazine degradation with transgenic plants has been reviewed by Dhankher et al. [284].

Endophytes with biodegradation ability can be added to the site to assist the plant with phytoremediation $[284,288]$. Genetic modification of endophytic bacteria is one pathway to develop the successful pesticide degradation by a plant, aided by bacteria associated with the plant. Endophytic bacteria may survive better than soil bacteria in field applications $[283,288]$. In phytoremediation, biodegradation in the rhizosphere and the plant are both important.

\subsubsection{Biodegradation of DDT}

The insecticide 1,1,1-trichloro-2,2-bis(p-chlorophenyl) ethane (DDT) is known to be persistent in the environment, and its use is banned in many locations [289]. However, it is still in use in Africa and India. It has very low solubility in water, about $0.001 \mathrm{mg} / \mathrm{L}$ and is more soluble in lipids $[289,290]$. The log of the octanol/water partition coefficient is 7.48 [292]. Eevers et al. have reported that DDT is taken up and transformed by several different plants [283]. Zucchini and pumpkin are two garden plants that take up DDT [254-256]. DDT can be removed from soil and transported into alfalfa, rye grass and tall fescue also [139]. Pan et al. [289] have reported their research to isolate a bacterium that biodegrades DDT and uses DDT as a carbon and energy source. The mineralization pathway is reported [289]. Nano-scale zero valent iron has been found to enhance the biodegradation rate of DDT [290]. Adding these nano particles several times resulted in biodegradation of the DDT [290] 
and further biodegradation of some of the initial degradation products. Spent mushroom waste (with white-rot fungus), and biosolids have been reported to be effective for degradation of DDT $[137,198]$. There are many plants that take up DDT and its metabolites and are beneficial in the remediation of DDT-contaminated soil [1,44,79,139,155,254-256,274,283].

Recently, Nurzhanova et al. [172] have reported their work on phytoremediation of soil containing DDT and metabolites of DDT. Table 1 contains data from their research [172]. In the table, DDE refers to 1,1-dichloro-2,2-bis(p-chlorophenyl) ethylene, and DDD refers to 1,1-dichloro-2,2-bis(p-chlorophenyl) ethane. When both chlorines on the benzene rings are in the para positions, 4 is used to show this. The two indicates that one of the chlorines is in the ortho position. MAC refers to the maximum allowable concentration, which is $0.1 \mathrm{mg} / \mathrm{kg}$ or $100 \mu \mathrm{g} / \mathrm{kg}$. In this soil, the average total concentration of DDT and the metabolites was $6.181 \mathrm{mg} / \mathrm{kg}$, which is 62 times the MAC.

Table 1. The concentration of DDT (1,1,1-trichloro-2,2-bis(p-chlorophenyl) ethane) and metabolites in soil and miscanthus after phytoremediation during one growing season *.

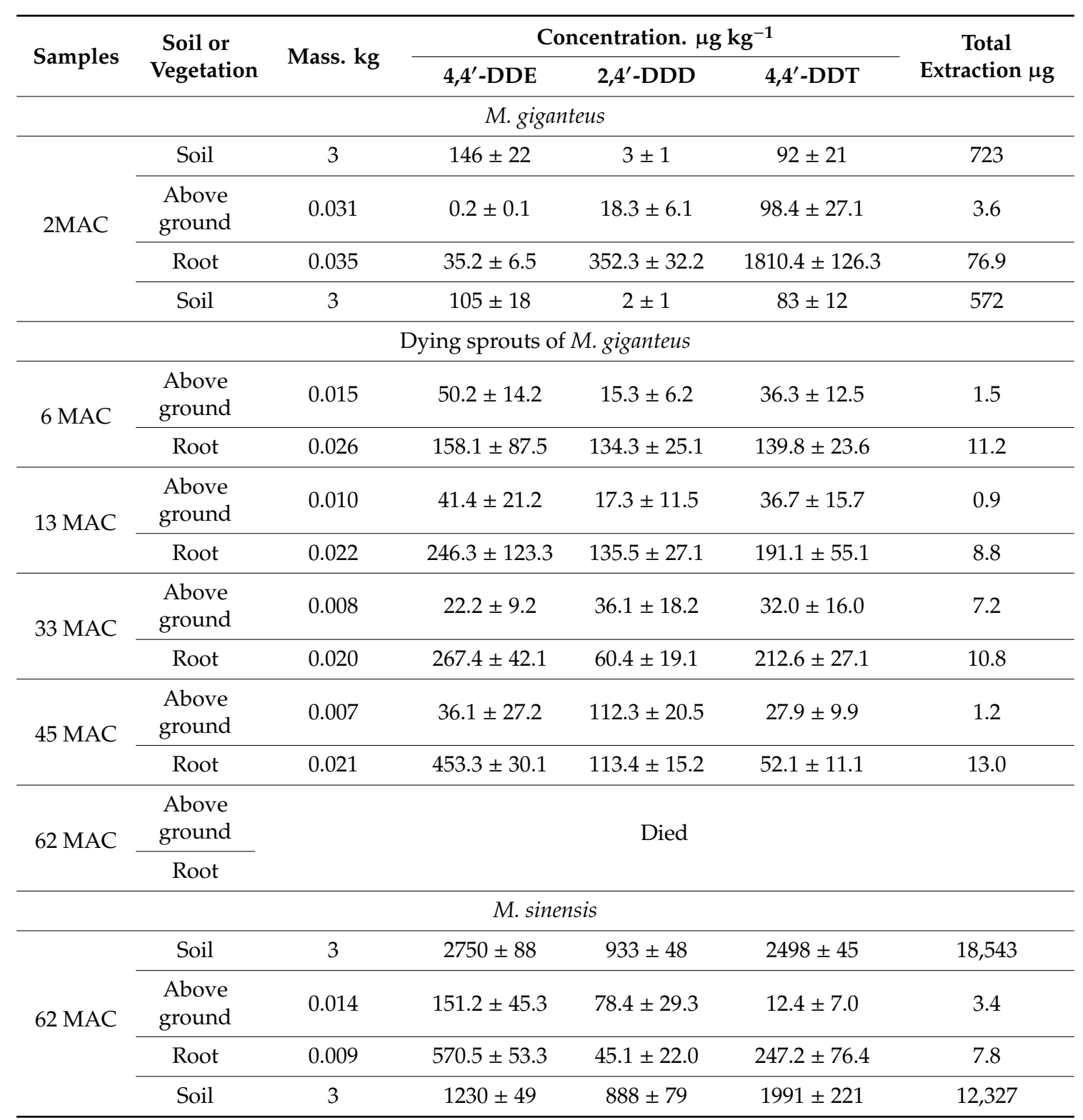

\footnotetext{
${ }^{*}$ MAC-maximum acceptable concentrations of metabolites of DDT in the soil $100 \mu \mathrm{g} \mathrm{kg}^{-1}$ from reference [172].
} 
The soil sample is from a contaminated field site in Kazakhstan that also had metal contamination [172]. The toxicity of the pesticide and the metabolites had a greater impact on Miscanthus $x$ giganteus, which is a triploid hybrid, compared to the diploid Miscanthus sinensis. For M.x giganteus the concentrations of DDT and DDE in the roots are greater than those in the aboveground biomass for all cases; however the concentration of DDD is larger in the aboveground biomass than in the root for the M. sinensis. The average height of the plants was $137.6 \mathrm{~cm}$ for the M.x giganteus for $2 \mathrm{MAC}$ and $75.3 \mathrm{~cm}$ for $M$. sinensis for 62MAC after one growing season [172]. The values for mass include any water that was present. The mass of DDT taken up by the plant was largest for the 2MAC experiment with M.x giganteus. The concentration of DDT in the roots is higher than the average value in the blended soil for 2MAC. When one blends clean soil and contaminated soil, one would expect to have some soil particles with much higher concentrations of DDT than the average value of $0.2 \mathrm{mg} / \mathrm{kg}$. In Table 1, for each experiment, the top soil sample data has values before the vegetation experiment and the lower soil sample data has values after the growing season. The notation $2 \mathrm{MAC}$ refers to two times the MAC or $2 \times 0.1 \mathrm{mg} / \mathrm{kg}=0.2 \mathrm{mg} / \mathrm{kg}$.

\subsubsection{Plant Selection}

Plants that are used for phytoremediation should be appropriate for the environmental conditions where they are planted. They should be plants that grow well locally under normal rainfall and temperature for the area. Plants that have a history of successful application in pesticide-contaminated soil should be considered for phytoremediation projects; see the listings of plants used previously for phytoremediation $[111,152,256,283]$. The toxicity of the pesticides in the soil to the plants may be important [54].

The cost of the plants and their establishment as well as the value of any products associated with the growth of the plants may affect the economics of the project $[54,57,104]$. Pidlisnyuk and coworkers have established miscanthus plots for phytoremediation applications with the goal of having an annual crop to harvest and use $[83,172,189]$.

\subsubsection{Soil Amendments}

Many beneficial amendments have been added to pesticide-contaminated soil that have increased biodegradation rates and extent while also reducing toxicity. Manure, biosolids, and compost provide nutrients and organisms with enzymes that may be beneficial for biodegradation in vegetated soil [189]. Nutrients and carbon and energy sources for microbial populations should be included in the plan. Bioaugmentation with microbial populations that have enzymes to degrade the pesticide of interest is helpful [277]. Arbuscular mycorrhizal fungi have been reported to be beneficial in phytoremediation because they have beneficial enzymes, and they stimulate microbial activity in the rhizosphere $[12,85]$. Substances that are not toxic and enhance solubility in the aqueous phase are beneficial because of the low water solubility of many pesticides. Since one goal of phytoremediation is to have land that can be used for its intended purposes, amendments that improve the land should be given a higher priority $[29,59,100]$. The $\mathrm{pH}$ that is desired for the phytoremediation and future use of the land should be included in developing the amendment plan.

The addition of enzymes with the capability to serve as catalysts for biodegradation of the pesticide of interest may be beneficial $[87,111,201,227]$. It is important for the pesticide and enzyme to find each other in the multiphase mix that includes soil, plant matter, and amendments. The water phase is a good place for this to happen if the pesticide has significant water solubility.

Water is important for phytoremediation and for agricultural productivity. In climates where low rainfall may be limiting productivity, soil amendments that improve the water-holding capacity for phytoremediation and future land use are expected to be beneficial. Adding organic carbon and/or biochar may improve water holding capacity, microbial numbers and microbial diversity $[10,15,20$, $23,27-29,37,59,97,100,128,130,191,225,226,251]$. Adsorption to the carbon should be expected, which makes the pesticides less available $[35,217]$. The population numbers and diversity of organisms 
present may be used to evaluate the quality of the soil $[59,100]$. Activated carbon additions to soil enhance adsorption and increase the fraction of a pesticide that is adsorbed. This reduces pesticide bioavailability $[27,35,37,43,64,76,89,166,178,183,211,217,224,233,237,249,265-268]$, which is beneficial when there are pesticide residues from past applications. The addition of biochar and/or activated carbon may reduce nutrient and trace metal availability $[166,266]$.

\subsubsection{Advantages and Disadvantages of Bioremediation and Phytoremediation}

In situ bioremediation and phytoremediation make use of natural processes and are appropriate for application in many locations where soil is contaminated with pesticides. One important issue is the time required for remediation because biological processes are slow compared to excavation and hauling to a landfill for hazardous substances or to an incinerator. It is well known that bioremediation and phytoremediation are less expensive than many alternative remediation processes such as soil removal followed by incineration or chemical oxidation $[72,74,110,136,214]$. The concentration of the pesticide in the soil may be an issue because biological processes are suitable for conditions where the pesticide is not toxic to the plants and microorganisms that are to be used for remediation. Yet, if it is needed as a $\mathrm{C}$ or $\mathrm{N}$ source for the micro-organism the concentration must be high enough to fulfill that need. Otherwise, co-metabolism with an additional substrate, perhaps supplied by the plant, will be more effective. Pesticide contamination that is at or near the soil surface is more appropriate for biological processes. Phytoremediation is generally most effective in the root zone of the vegetation $[136,214]$. There is research progress in developing new genetic capability for biodegradation and phytoremediation $[40,136,148,277,289]$.

\section{Implementing and Monitoring Phytoremediation}

There are some inexpensive approaches to implementing and monitoring phytoremediation. The initial starting point may be pesticide-contaminated soil where there is knowledge of a spill or where plant growth is poor or plants do not survive because of pesticides. Soil amendments such as compost, manure, and plant residues (such as leaves) can be added to the contaminated soil to add microorganisms, nutrients, and organic carbon to obtain an amended soil with about $5 \%$ to $10 \%$ amendments. One can blend this amended soil into clean productive soil to obtain a 50/50 soil and a 10/90 soil with $10 \%$ of the contaminated soil to reduce toxicity. The different soils can be placed in pots and plants can be transplanted so there is one plant in each pot. The experiment may include (1) The original polluted soil, (2) The original soil with amendments, (3) The 50/50 soil with amendments, and (4) The 10/90 soil with 10\% polluted soil with amendments. With three replicates of each soil mixture, there would be 12 pots with one plant transplanted into each pot. These pots can be watered regularly and managed in an environment with good natural light and appropriate temperature.

The fate of the vegetation can be monitored with respect to plant survival and plant growth. The height and mass of the plants can be measured and recorded. There is value in measuring the concentrations of nitrogen, phosphorus, organic carbon, and microbial numbers in the original polluted soil, the clean soil, and the soils with amendments. The concentration of the pesticide should be measured in the original contaminated soil and after the plant growth experiments. Since nematodes, arthropods, and earthworms are measures of soil health, experiments with soil fauna may be beneficial to understanding the fate of these organisms in pesticide contaminated soil.

Once the initial experiments are finished, one may wish to begin the field experiment; however, the results may also suggest that further experimentation is needed. For example, experiments could be carried out with several different plants to try to find a plant that grows well in the polluted soil with amendments and without soil dilution.

\section{Conclusions}

In many countries significant land area is contaminated with pesticides and/or contains pesticide residues that are of concern. Soil quality is very important for agricultural production, and improving 
productivity is a high priority because of the need for food, feed, and other products. The biodegradation of pesticides in soil is advancing at many locations. New genetic developments will facilitate this through use of engineered organisms where they are permitted.

Earlier reviews have been cited in this work and recent developments noted. Research on biological remediation methods for pesticides in soil and water continues to be an important research thrust in many countries. Soil amendments that provide genetic diversity and food sources for microbial populations are beneficial. Endophytes with the ability to degrade pesticides are being developed and applied with plants that take up and transform pesticides.

Phytoremediation technologies are very appropriate for application to soils containing pesticides in many countries. New initiatives to develop plants for phytoremediation that can be harvested and used beneficially are receiving research attention. The knowledge and equipment that are needed to implement phytoremediation at field sites are available in many parts of the world.

Author Contributions: Conceptualization, D.N.T., L.E.E., G.M.H., and L.C.D.; Methodology, D.N.T., G.M.H., L.C.D., A.N., and V.P.; Analysis, A.N. and V.P.; Investigation, D.N.T., L.E.E., G.M.H., S.I.A., M.G., L.C.D., A.N., and V.P. Resources, A.N. and V.P. Data Curation, A.N. and V.P. Writing, Reviewing and Editing, D.N.T., L.E.E., G.M.H., S.I.A., M.G., L.C.D., A.N., and V.P. Supervision, L.E.E., G.M.H., L.C.D., A.N., and V.P. Project Administration, L.E.E., G.M.H., L.C.D., A.N., and V.P. Funding aquisition, D.N.T., L.E.E., G.M.H., A.N., and V.P. All authors have read and agreed to the published version of the manuscript.

Funding: This research was partially funded by NATO grant number G4687.

Acknowledgments: This research was sponsored by the United States Department of State, Bureau of Educational and Cultural Affairs (ECA) administered by the Council of International Exchange of Scholars, the scholar division of the Institute of International Education as part of a Fulbright Visiting Scholar Grant. This research was partly supported by NATO SPS MYP G4687.

Conflicts of Interest: The authors declare no conflict of interest.

\section{References}

1. Abhilash, P.C.; Singh, N. Effect of growing Sesamum indicum L. on enhanced dissipation of lindane (1,2,3,4,5,6-Hexachlorhexane) from soil. Int. J. Phytorem. 2010, 12, 440-453. [CrossRef]

2. Adeyemi, D.; Ukpo, G.; Anyakora, C.; Unyimadu, J.P. Organochlorine Pesticide Residues in Fish Samples from Lagos Lagoon, Nigeria. Am. J. Environ. Sci. 2008, 4, 649-653. [CrossRef]

3. Ahmad, R.; Salem, N.M.; Estaitieh, H. Occurrence of organochlorine pesticides in eggs, chicken and meat in Jordan. Chemosphere 2010, 78, 667-671. [CrossRef] [PubMed]

4. Aislabie, J.M.; Richards, N.K.; Boul, H.L. Microbial degradation of DDT and its residues-A review. N. Z. J. Agric. Res. 1997, 40, 269-282. [CrossRef]

5. Aktar, W.; Sengupta, D.; Chowdhury, A. Impact of pesticides use in agriculture: Their benefits and hazards. Interdiscip. Toxicol. 2009, 2, 1-12. [CrossRef] [PubMed]

6. Alamdar, A.; Syed, J.H.; Malik, R.N.; Katsoyiannis, A.; Liu, J.; Li, J.; Zhang, G.; Jones, K.C. Organochlorine pesticides in surface soils from obsolete pesticide dumping ground in Hyderabad City, Pakistan: Contamination levels and their potential for air-soil exchange. Sci. Total Environ. 2014, 470-471, 733-741. [CrossRef] [PubMed]

7. Alexander, M. Aging, bioavailability, and overestimation of risk from environmental pollutants. J. Environ. Sci. Technol. 2000, 34, 4259-4265. [CrossRef]

8. Aliyu, H.G.; Adamu, H.M. The potential of maize as phytoremediation tool of heavy metals. Eur. Sci. J. 2014, 10, 32-37.

9. Amato, C.D.; Torres, J.P.M.; Malm, O. DDT (Dichlorodiphenyltrichloroethane): Toxicity and environmental contamination-A review. Quim. Nova 2002, 15, 995-1002.

10. Anderson-Teixeira, K.J.; Davis, S.C.; Masters, M.D.; Delucia, E.H. Changes in soil organic carbon under biofuel crops. GCB Bioenergy 2009, 1, 75-96. [CrossRef]

11. AOAC. Official Methods of Analysis of AOAC; Horwitz, W., Latimer, G.W., Eds.; AOAC International: Rockville, MD, USA, 2005; Available online: www.aoac.org (accessed on 3 February 2020). 
12. Aranda, E.; Scervino, J.M.; Godoy, P.; Reina, R.; Ocampo, J.A.; Wittich, R.M.; García-Romera, I. Role of arbuscular mycorrhizal fungus Rhizophagus custos in the dissipation of PAHs under root-organ culture conditions. Environ. Pollut. 2013, 181, 182-189. [CrossRef] [PubMed]

13. Aslund, M.W.; Zeeb, B.A.; Aslund, M.W.; Zeeb, B.A. A Review of Recent Research Developments into the Potential for Phytoextraction of Persistent Organic Pollutants (Pops) from Weathered, Contaminated Soil. In Application of Phytotechnologies for Cleanup of Industrial, Agricultural, and Wastewater Contamination; NATO Science for Peace and Security Series C: Environmental Security; Kulakow, P., Pidlisnyuk, V., Eds.; Springer: Dordrecht, The Netherlands, 2009; pp. 35-59.

14. ASP (Africa Stockpiles Programme). Obsolete Pesticide Stocks: An Issue of Poverty. Africa Stockpiles Programme. 2003. Available online: http://www.africastockpiles.org/pdf/ (accessed on 3 February 2020).

15. Atkinson, C.; Fitzgerald, J.; Hipps, N. Potential mechanisms for achieving agricultural benefits from biochar application to temperate soils: A review. Plant Soil 2010, 337, 1-18. [CrossRef]

16. Bajak, A. The Developing World is Awash in Pesticides. Does it Have to Be? 2012. Available online: https://ensia.com/features/developing-world-pesticides/ (accessed on 3 February 2020).

17. Baleguel, N.P.; Dobson, H.M.; Matthews, G.A. Vector management is crucial for healthier farmers. Int. Pest Control 2007, 49, 70-71.

18. Baleguel, N.P.; Ghogomu, T.R.; Baleguel, P.D. Spraying from a boat to control Simulium larvae along the Sanaga River, Cameroon. Int. Pest Control 2011, 53, 144-146.

19. Basheer, C.; Alnedhary, A.A.; Rao, B.S.M.; Lee, H.K. Determination of carbamate pesticides using micro-solid-phase extraction combined with high-performance liquid chromatography. J. Chromatogr. A 2009, 1216, 211-216. [CrossRef]

20. Beesley, L.; Moreno-Jiménez, E.; Gomez-Eyles, J.L. Effects of biochar and greenwaste compost amendments on mobility, bioavailability and toxicity of inorganic and organic contaminants in a multi-element polluted soil. Environ. Pollut. 2010, 158, 2282-2287. [CrossRef]

21. Beesley, L.; Moreno-Jimenez, E.; Gomez-Eyles, J.L.; Harris, E.; Robinson, B.; Sizmur, T. A review of biochars' potential role in remediation, revegetation and restoration of contaminated soils. Environ. Pollut. 2011, 159, 3269-3282. [CrossRef]

22. Bisht, S.; Pandey, P.; Bhargava, B.; Sharma, S.; Kumar, V.; Sharma, K.D. Bioremediation of polyaromatic hydrocarbons (PAHs) using rhizosphere technology. Braz. J. Microbiol. 2015, 46, 7-21. [CrossRef]

23. Blackwell, P.; Reithmuller, G.; Collins, M. Biochar Application to Soil. In Biochar for Environmental Management: Science and Technology; Lehmann, J., Joseph, S., Eds.; Earthscan: London, UK, 2009.

24. Blankespoor, B.; Dasgupta, S.; Dhouibi, W.; Lagnaoui, A.; Meisner, C.; Salah, H.B. Stockpiles of Obsolete Pesticides: Threats to Ecosystems and Biodiversity; Energy and Environment Research, Development Research Group, World Bank: Washington, DC, USA, 2009; Available online: http://econ.worldbank.org/research (accessed on 3 February 2020).

25. Blaszak, M.; Pelech, R.; Graczyk, P. Screening of microorganisms for biodegradation of simazine pollution (obsolete pesticide Azotop 50 WP). Water Air Soil Pollut. 2011, 220, 373-385. [CrossRef]

26. Bourgeois, E.; Dequiedt, S.; Lelievre, M.; van Oort, F.; Lamy, I.; Maron, P.A.; Ranjard, L. Positive effect of the Miscanthus crop on microbial diversity in wastewater-contaminated soil. Environ. Chem. Lett. 2015, 13, 495-501. [CrossRef]

27. Brändli, R.C.; Hartnik, T.; Henriksen, T.; Cornelissen, G. Sorption of native polyaromatic hydrocarbons (PAH) to black carbon and amended activated carbon in soil. Chemosphere 2008, 73, 1805-1810. [CrossRef] [PubMed]

28. Briceno, G.; Palma, G.; Duran, N. Influence of organic amendment on the biodegradation and movement of pesticides. Crit. Reviews in Environ. Sci. Technol. 2007, 37, 233-271. [CrossRef]

29. Brussaard, L. Biodiversity and ecosystem functioning in soil. AMBIO 1997, 26, 563-569.

30. Buczynska, A.; Szadkowska-Stanczyk, I. Identification of health hazards to rural population living near pesticide dump sites in Poland. Int. J. Occup. Environ. Health 2005, 18, 331-339.

31. Cai, X.; Zheng, X.; Wang, D. Land availability for biofuel production. Environ. Sci. Technol. 2011, 45, 334-339. [CrossRef]

32. California Integrated Waste Management Board. Organics: Persistence and Degradation of Pesticides in Composting. 2002. Available online: http://www.calrecycle.ca.gov/publications/Documents/Organics/ 44200015.pdf (accessed on 3 November 2016).

33. Carson, R. Silent Spring; Riverside Press; Houghton Mifflin: Boston, MA, USA, 1962; pp. $20-27$. 
34. Castelo-Grande, T.; Augusto, P.A.; Monteiro, P.; Estevez, A.M.; Barosa, D. Remediation of soils contaminated with pesticides: A review. Int. J. Environ. Analyt. Chem. 2010, 90, 438-467. [CrossRef]

35. Centofanti, T.; McConnell, L.L.; Chaney, R.L.; Beyer, W.N.; Andrade, N.A.; Hapeman, C.J.; Torrents, A.; Nguyen, A.; Anderson, M.O.; Novak, J.M.; et al. Organic amendments for risk mitigation of organochlorine pesticide residues in old orchard soils. Environ. Pollut. 2016, 210, 182-191. [CrossRef]

36. Chakraborty, P.; Zhang, G.; Li, J.; Xu, Y.; Liu, X.; Tanabe, S.; Jones, K.C. Selected organochlorine pesticides in the atmosphere of major Indian cities: Levels, regional versus local variations, and sources. Environ. Sci. Technol. 2010, 44, 8038-8043. [CrossRef]

37. Chan, K.Y.; Van Zwieten, L.; Meszaros, I.; Downie, A.; Joseph, S. Using poultry litter biochars as soil amendments. Aust. J. Soil Res. 2008, 46, 437-444. [CrossRef]

38. Chappell, J. Phytoremediation of TCE in Groundwater Using Populus Status Report Prepared for the USEPA Technology Innovation Office under a National Network of Environmental Management Studies Fellowship; U.S. Environmental Potection Agency: Washington, DC, USA, 1997; pp. 1-38.

39. Chaudhry, M.Q.; MacNicoll, A.D. Mechanisms of Insecticide Resistance. In Pesticide Outlook; Royal Society of Chemistry: London, UK, 1998; pp. 23-28.

40. Chaudhry, Q.; Shroder, P.; Werck-Reihhart, D.; Grajek, W.; Marecik, R. Prospects and limitations of phytoremediation for the removal of persistent pesticides in the environment. Environ. Sci. Pollut. Res. 2002, 9, 4-19. [CrossRef]

41. Chen, S.; Edwards, C.; Subler, S. A microcosm approach for evaluating the effects of the fungicides benomyl and captan on soil ecological process and plant growth. Appl. Soil Ecol. 2001, 18, 69-82. [CrossRef]

42. Chen, Y.; Duan, J.; Luo, Y. Investigation of agricultural residues pyrolysis behavior under inert and oxidative conditions. J. Anal. Appl. Pyrolysis 2008, 83, 165-174. [CrossRef]

43. Cho, Y.M.; Ghosh, U.; Kennedy, A.J.; Grossman, A.; Ray, G.; Tomaszewski, J.E.; Smithenry, D.W.; Bridges, T.S.; Luthy, R.G. Field application of activated carbon amendment for in-situ stabilization of polychlorinated biphenyls in marine sediment. Environ. Sci. Technol. 2009, 43, 3815-3823. [CrossRef] [PubMed]

44. Chu, W.K.; Wong, M.H.; Zhang, J. Accumulation, distribution and transformation of DDT and PCBs by Phragmites australis and Oriza sativa L: I. Whole plant study. Environ. Geochem. Health 2006, 28, 159-168. [CrossRef] [PubMed]

45. Coats, J.R. What happens to degradable pesticides? Chemtech 1993, 23, 25-29.

46. Cooper, J.; Dobson, H. The benefits of pesticides to mankind and the environment. Crop Prot. 2007, 9 , 1337-1348. [CrossRef]

47. Coppella, S.J.; Cruz, N.D.; Payne, G.F.; Pogell, B.M.; Speedie, M.K.; Karns, J.S.; Sybert, E.M.; Connor, M.A. Genetic engineering approach to toxic waste management case study for organophosphate waste treatment. Biotechnol. Prog. 1990, 6, 76-81. [CrossRef]

48. Crecchio, C.; Curci, M.; Pizzigallo, M.; Ricciuti, P.; Ruggiero, P. Molecular approaches to investigate herbicide-induced bacterial community changes in soil microcosms. Biol. Fertil. Soils 2001, 33, 460-466. [CrossRef]

49. Culliney, T.W. Role of Arthropods in maintaining soil fertility. Agriculture 2013, 3, 629-659. [CrossRef]

50. Cunningham, S.D.; Shann, J.R.; Crowley, D.E.; Anderson, T.A. Phytoremediation of Contaminated Water and Soil. In Phytoremediation of Soil and Water Contaminants; Kruger, E.L., Anderson, T.A., Coats, J.R., Eds.; American Chemical Society Symposium Series: Washington, DC, USA, 1997; Volume 664, pp. 12-17.

51. Darko, G.; Acquaah, S.O. Levels of Organochlorine Pesticides Residues in Meat. Int. J. Environ. Sci. Technol. 2007, 4, 521-524. [CrossRef]

52. Dasgupta, S.; Meisner, C.; Wheeler, D. Stockpiles of Obsolete Pesticides and Cleanup Priorities. In Policy Research Working Paper No 4893; The World Bank Development Research Group; Environment and Energy Team; World Bank: Washington, DC, USA, 2009.

53. Davis, L.; Erickson, L.; Hattiarachchi, G.; Mengarelli, J.; Pidlisnyuk, V.; Roozeboom, K.; Stefanovska, T.; Tatarina, N. Phytoremediation with Miscanthus Produced for Bioenergy. In Proceedings of the 11th International Phytotechnologies Conference, Herklion, Greece, 30 September-3 October 2014; p. 313.

54. Davis, L.C.; Castro-Diaz, S.; Zhang, Q.; Erickson, L.E. Benefits of vegetation for soils with organic contaminants. Crit. Rev. Plant Sci. 2002, 21, 457-491. [CrossRef]

55. De Lurdes Dinis, M.; Fiuza, A. Exposure Assessment to Hazardous Pesticides-Strategies to Reduce Human and Environmental Risks. In Environmental Security Assessment and Management of Obsolete Pesticides in 
Southeast Europe; Simeonov, L., Macaev, F., Simeonova, B., Eds.; NATO Science for Peace and Security Series C: Environmental Security; Springer: Dordrecht, The Netherland, 2012; pp. 69-84.

56. Dem, S.B.; Cobb, J.M.; Mullins, D.E. Pesticide Residues in Soil and Water from Four Cotton Growing Areas of Mali, West Africa. J. Agric. Food Environ. Sci. 2007, 1, 1-12.

57. Dickinson, N.M.; Baker, A.J.M.; Doronila, A.; Laidlaw, S.; Reeves, R.D. Phytoremediation of inorganics: Realism and synergies. Int. J. Phytorem. 2009, 11, 97-114. [CrossRef] [PubMed]

58. Dimas, S. Danger of Obsolete Pesticides. In Caution! Dangerous Chemicals, Obsolete Pesticides; Wielsaw, S.K., Ed.; Centre for European Policy Studies: Brussels, Belgium, 2007; pp. 108-114. Available online: www.ceps.eu/ ceps/dld/1663/pdf (accessed on 29 June 2012).

59. Doran, J.W.; Zeiss, M.R. Soil health and sustainability: Managing the biotic component of soil quality. Appl. Soil Ecol. 2000, 15, 3-11. [CrossRef]

60. Dory, S.L.; Shang, T.Q.; Wilson, A.M.; Tangen, J.; Westergreen, A.D.; Newman, L.A.; Strand, S.E.; Gordon, M.P. Enhanced metabolism of halogenated hydrocarbons in transgenic plants containing mammalian cytochrome P4s0 2E1. Proc. Natl. Acad. Sci. USA 2000, 97, 6287-6291.

61. Drozda, V. The problem and obsolete pesticides disposal in Ukraine: Solution, Economy. In Proceedings of the 6th International HCH and Pesticide Forum, Poznan, Poland, 20-22 March 2001; pp. 143-147.

62. Duiker, S.W.; Stehouwer, R. Earthworms, Penn State Extension. 2016. Available online: https://extension.psu. edu/ (accessed on 3 February 2020).

63. Đurović, R.; Đorđević, T.; Radivojević, L.J.; Šantrić, L.J.; Gajić Umiljendić, J. Multiresidue Analysis of Pesticides in Soil by Liquid-Solid Extraction Procedure. Pestic. Phytomed. 2012, 27, 239-244. [CrossRef]

64. Elad, Y.; David, D.R.; Harel, Y.M.; Borenshtein, M.; Ben Kalifa, H.; Silber, A.; Graber, E.R. Induction of systemic resistance in plants by biochar, a soil-applied carbon sequestering agent. Phytopathology 2010, 100, 913-921. [CrossRef]

65. Embassy of the Republic of Congo. About Congo: Congo Bassin; Embassy of the Republic of Congo: Washington, DC, USA, 2016; Available online: http://www.ambacongo-us.org/en-us/aboutcongo/congobasin. aspx (accessed on 30 November 2016).

66. Environment Canada. Canada's National Implementation Plan under the Stockholm Convention on Persistent Organic Pollutants; Environment and Climate Change Canada: Gatineau, QC, Canada, 2006; 159p, Available online: www.pops.int/documents/implementation/nips/submissions/default.htm (accessed on 16 January 2012).

67. Eqani, S.A.; Malik, R.N.; Cincineli, A.; Zhang, G.; Mohammad, A.; Qadir, A.; Rashid, A.; Bokhari, H.; Jones, K.C.; Katsoyiannis, A. Uptake of organichlorine pesticides (OCPs) and polychlorinated biphenyls (PCBs) by river water fish: The case of River Chenab. Sci. Total Environ. 2013, 450-451, 83-91. [CrossRef]

68. FAO. FAOSTAT: Pesticide Use. 2017. Available online: http://www.fao.org/faostat/en/\#data/RP (accessed on 11 January 2017).

69. FAO. Prevention and Disposal of Obsolete Pesticides: Inventory and Environmental Risk Assessment. 2014. Available online: http://www.fao.org/agriculture/crops/obsolete-pesticides/how-deal/inventory-risk/en/ (accessed on 15 September 2014).

70. FAO. A New Deal to Rid Eastern Europe, the Caucasus and Central Asia of Obsolete Pesticides. 2012. Available online: http://www.fao.org/news/story/en/item/134629/icode/ (accessed on 25 October 2016).

71. FAO. Pesticide Problem Solved in Paraguay. 2011. Available online: http://www.fao.org/agriculture/crops/ news-events-bulletins/detail/en/item/55048/icode/2/?no_cache=1 (accessed on 3 February 2020).

72. FAO. The Preparation of Inventories of Pesticides and Contaminated Materials; FAO Pesticide Disposal Series 1; FAO: Rome, Italy, 2010; Available online: http://www.fao.org/docrep/013/i1724e/i1724e.pdf (accessed on 23 November 2016).

73. FAO. Baseline Study on the Problem of Obsolete Pesticides Stocks. No. 9, Viale Delle Terme di Caracalla, Rome. 2001. Available online: http://www.fao.org/docrep/003/x8639e/x8639e00.htm\#TopOfPage (accessed on 21 November 2016).

74. FAO. Obsolete Pesticides: Problems, Prevention and Disposal. Plant Production and Protection Division; FAO: Rome, Italy, 1998. 
75. FAO. Disposal of Bulk Quantities of Obsolete Pesticides in Developing Countries. In Provisional Technical Guidelines No. 4; Food and Agriculture Organization of the United Nations: Rome, Italy, 1996; Available online: http://www.fao.org/fileadmin/user_upload/obsolete_pesticides/docs/w1604e.pdf (accessed on 3 February 2020).

76. Fagervold, S.K.; Chai, Y.; Davis, J.W.; Wilken, M.; Cornelissen, G.; Ghosh, U. Bioaccumulation of polychlorinated dibenzo-p-dioxins/dibenzofurans in Eisenia fetida from floodplain soils and the effect of activated carbon amendment. Environ. Sci. Technol. 2010, 44, 5546-5552. [CrossRef]

77. Fenoll, J.; Hellín, P.; Marín, C.; Martínez, C.M.; Flores, P. Multiresidue Analysis of Pesticides in Soil by Gas Chromatography with Nitrogen-Phosphorus Detection and Gas Chromatography Mass Spectrometry. J. Agric. Food Chem. 2005, 53, 7661-7666. [CrossRef]

78. Figala, J.; Vranova, V.; Rejsek, K.; Formanek, P. Giant miscanthus (Miscanthus x giganteus greef et deu.)-A promising plant for soil remediation: A mini review. Acta Universitatis Agriculturae et Silviculturea Mendalianae Brunensis 2015, 63, 224102246. [CrossRef]

79. Fisko, S.; Rutter, A.; Zeeb, B. Potential phytoextraction of PCB from contaminated soil using weed. J. Sci. Total Environ. 2010, 408, 3469-3476.

80. Fogg, P.; Boxall, A.B.A.; Walker, A. Degradation of pesticides in biobeds: The effect of concentration and pesticide mixtures. J. Agric. Food Chem. 2003, 51, 5344-5349. [CrossRef] [PubMed]

81. Fogg, P.; Boxall, A.B.A.; Walker, A.; Jukes, A. Degradation and leaching potential of pesticides in biobed systems. Pest Manag. Sci. 2004, 60, 645-654. [CrossRef]

82. Fontem, D.A.; Gumedzoe, M.Y.D.; Nono-Womdim, R. Biological constraints in tomato production in the western highlands of Cameroon. Tropicultura 1998, 16, 89-92.

83. Fruhwirth, P.; Liebhard, P. Miscanthus sinensis Giganteus. Produktion, Inhaltsstoffe und Verwertung. In Miscanthus sinensis Giganteus. Chinaachilf als nachwachsender Rohstoff; Landliches Forbildingsinstitut und Landwirtschaftskammer Osterreich: Wien, Austria, 2004; pp. 34-38. (In German)

84. Galuszka, A.; Migaszewski, Z.M.; Manecki, P. Pesticide burial grounds in Poland: A review. Environ. Int. 2011, 37, 1265-1272. [CrossRef]

85. Gao, Y.; Li, Q.; Ling, W.; Zhu, X. Arbuscular mycorrhizal phytoremediation of soils contaminated with phenanthrene and pyrene. J. Hazard. Mater. 2011, 185, 703-709. [CrossRef]

86. Garbisu, C. Phytoremediation: A technology using green plants to remove contaminants from polluted areas. Rev. Environ. Health 2002, 17, 63-68. [CrossRef]

87. Gianfreda, L.; Bollag, J.-M. Isolated Enzymes for the Transformation and Detoxification of Organic Pollutants. In Enzymes in the Environment: Activity, Ecology and Applications; Burns, R.G., Dick, R., Eds.; Marcel Dekker: New York, NY, USA, 2002; pp. 491-538.

88. Golubev, I.A. Handbook of Phytoremediation; Nova Science Publishers: Hauppauge, NY, USA, 2011.

89. Gomez-Eyles, J.L.; Sizmur, T.; Collins, C.D.; Hodson, M.E. Effects of biochar and the earthworm Eisenia fetida on the bioavailability of polycyclic aromatic hydrocarbons and potentially toxic elements. Environ. Pollut. 2011, 159, 616-622. [CrossRef]

90. Government of Canada. Canada's National Implementation Plan under the Stockholm Convention on Persistent Organic Pollutants; Government of Canada: Ottawa, ON, Canada, 2006. Available online: www.pops.int/ documents/implementation/nips.pdf (accessed on 12 July 2012).

91. Grama, M.; Pinzaru, I.; Mirza, C.; Tertea, V. Initiatives and Actions on the Elimination of Obsolete Pesticides Risks/Hazards in the Republic of Moldova. In Environmental Security Assessment and Management of Obsolete Pesticides in Southeast Europe; Simeonov, L., Macaev, F., Simeonova, B., Eds.; NATO Science for Peace and Security Series C: Environmental Security; Springer: Dordrecht, The Netherlands, 2012; pp. 433-448.

92. Guyot, C.; Chenivesse, D. A Simple and Affordable System to Prevent Water Contamination. ICMEDITION; Bayer Crop Science: Monheim am Rhein, Germany, 2006; pp. 31-33.

93. Hagerbaumer, A.; Hoss, S.; Heininger, P.; Traunspurger, W. Experimental studies with nematodes in ecotoxicology: An overview. J. Nematol. 2015, 47, 11-27.

94. Hajjar, M.J. Obsolete pesticides in Saudi Arabia: Problems, prevention and disposal. MOJ Toxicol. 2015, 1, 1-6. [CrossRef]

95. Hajjar, M.J. The persistent organic pollutants (POPs) in the Middle East Arab Countries. Int. J. Agron. Plant Prod. 2012, 3, 11. 
96. Hamada, M.; Wintersteiger, R. Determination of phenylurea herbicides in drinking water. J. Planar Chromatogr.-Mod. TLC 2002, 15, 11-18. [CrossRef]

97. Hamer, U.; Marschner, B.; Brodowski, S.; Amelung, W. Interactive priming of black carbon and glucose mineralization. Org. Geochem. 2004, 35, 823-830. [CrossRef]

98. Harmsen, J. An African Approach for Risk Reduction of Soil Contamination by Pesticides; Alterra Report 1742; Alterra: Wageningen, The Netherlands, 2009.

99. Harmsen, J.; Ammati, M.; Davis, M.; Sylla, C.H.; Sidibe, T.; Kone, T.H.; Diallo, A.; Demba, A.S.Y. An African Approach for Risk Reduction of soil Contaminated by Obsolete Pesticides. In Proceedings of the 10th International In Situ and On-Site Bioremediation Symposium, Baltimore, MD, USA, 5-9 May 2009.

100. Harris, J.A. Measurements of the soil microbial community for estimating the success of restoration. Eur. J. Soil Sci. 2003, 54, 801-808. [CrossRef]

101. Haylamicheal, I.D.; Dalvie, M.A. Disposal of obsolete pesticides, the case of Ethiopia. Environ. Int. 2009, 35, 667-673. [CrossRef]

102. Haynes, W.M. CRC Handbook of Chemistry and Physics, 97th ed.; Haynes, W.M., Ed.; CRC Press: Boca Raton, FL, USA, 2016.

103. Hazardous Waste and Information Center. Use of Landfarming to Remediate Soils Contaminated with Pesticide Waste; Waste Management and Research Center, University of Illinois. 1994. Available online: http://www.istc.illinois.edu/info/library_docs/tr/tr19.pdf (accessed on 21 October 2016).

104. Hemen, P. Metal hyperaccumulation in plants: A review focusing on phytoremediation technology. J. Environ. Sci. Technol. 2011, 4, 118-138.

105. Henriques, W.; Jeffers, R.D.; Lacher, T.E.; Kandell, R.J. Agrochemical use on banana plantations in Latin America: Perspectives on ecological risk. Environ. Tox. Chem. 1997, 16, 91-99. [CrossRef]

106. Hippelein, M.; McLachlan, M.S. Soil/Air Partitioning of Semivolatile Organic Compounds. 1. Method Development and Influence of Physical-Chemical Properties. Environ. Sci. Technol. 1998, 32, 310-316. [CrossRef]

107. Hladik, M.L.; Smalling, K.L.; Kuivila, K.M. Methods of Analysis-Determination of Pyrethroid Insecticides in Water and Sediment Using Gas Chromatography/Mass Spectrometry; U.S. Geological Survey Techniques and Methods: Reston, VA, USA, 2009; 18p.

108. Hogendoorn, E.A.; Huls, R.; Dijkman, E.; Hoogerbrugge, R. Microwave assisted solvent extraction and coupled-column reversed-phase liquid chromatography with UV detection use of an analytical restricted-access-medium column for the efficient multi-residue analysis of acidic pesticides in soils. J. Chromatogr. A 2001, 938, 23-33. [CrossRef]

109. Holland, N.T.; Duramad, P.; Rothman, N.; Figgs, L.W.; Blair, A.; Hubbard, A.; Smith, M.T. Micronucleus frequency and proliferation in human lymphocytes after exposure to herbicide 2,4-dichlorophenoxyacetic acid in vitro and in vivo. J. Mutation Res. Gen. Toxic Environ. Mutagen. 2002, 521, 165-178. [CrossRef]

110. Huang, J.W.; Cunningham, S.D. Lead Phytoextraction: Species Variation in Lead Uptake and Translocation. New Phytol. 1996, 134, 75-84. [CrossRef]

111. Hussain, S.; Siddique, T.; Arshad, M.; Saleem, M. Bioremediation and phytoremediation of pesticides: Recent advances. Crit. Rev. Environ. Sci. Technol. 2009, 39, 843-907. [CrossRef]

112. ITRC (Interstate Technology and Regulatory Cooperation). Phytotechnology Technical and Regulatory Guidance Document. 2001. Available online: http://www.itrcweb.org/Guidance/GetDocument? documentID=64 (accessed on 25 November 2016).

113. ITRC. Emerging Technologies for the Remediation of Metals in Soils-Phytoremediation. 1997. Available online: www.itrcweb.org (accessed on 10 December 2014).

114. Javaid, M.K.; Ashiq, M.; Tahir, M. Review article: Potential of biological agents in decontamination of agricultural soil. Scientifica 2016, 2016. [CrossRef] [PubMed]

115. Jeffries, P.; Gianinazzi, S.; Perotto, S.; Turnan, K.; Barea, J.M. The contribution of arbuscular mycorrhizal fungi in sustainable maintenance of plant health and soil fertility. Biol. Fertil. Soils 2003, 37, 1-16. [CrossRef]

116. Joner, E.J.; Leyval, C. Phytoremediation of organic pollutants using mycorrhizal plants: A new aspect of rhizosphere interactions. Agronomie 2003, 23, 495-502. [CrossRef]

117. Vijgen, J.; Egenhofer, C. Obsolete Pesticides: A Ticking Time Bomb Why We Have to Act Now. CEPS Special Report. 2009. Available online: http://aei.pitt.edu/10965/1/1841[1].pdf (accessed on 25 October 2016). 
118. Jorgensen, R.P.; Spliid, N.H. Accumulation of pesticides in anaerobic clayey till-controls and implications for groundwater. Groundw. Monit. Remed. 2016, 36, 43-53. [CrossRef]

119. Kannan, K.; Battula, S.; Loganathan, B.G.; Hong, C.S.; Lam, W.H.; Villeneuve, D.L.; Sajwan, K.; Giesy, J.P.; Aldons, K.M. Geographical Distribution and Accumulation Features of Organochlorine Residues in Fish in Tropical Asia and Oceania. Environ. Sci. Technol. 1995, 29, 2673-2683. [CrossRef]

120. Kapoor, J.; Rao, A.L.J. Spectrophotometric determination of ziram and zineb using 4-(2-pyridylazo) resorcinol. Pestic. Manag. Sci. 1994, 42, 109-112. [CrossRef]

121. Karanasios, E.; Tsiropoulos, N.G.; Karpouzas, D.G.; Ehaliotis, C. Degradation and adsorption of pesticides in compost-based biomixtures as potential substrates for biobeds in southern Europe. J. Agric. Food Chem. 2010, 58, 9147-9156. [CrossRef]

122. Karthikeyan, R.; Davis, L.C.; Erickson, L.E.; Al-Khatib, K.; Kulakow, P.A.; Barnes, P.L.; Hutchinson, S.L.; Nurzhanova, A.A. Potential for plant-based remediation of pesticide-contaminated soil and water using nontarget plants such as trees, shrubs and grasses. Crit. Rev. Plant Sci. 2004, 23, 91-101. [CrossRef]

123. Keller-Byrne, J.E.; Khuder, S.A.; Schaub, E.A.; O'Neal, M. A Meta-analysis of Non-Hodgkin's Lymphoma among Farmers in the Central United States. Am. J. Ind. Med. 1997, 31, 442-444. [CrossRef]

124. Kiflom, W.; Wandiga, G.S.O.; Nganga, P.K.; Kamau, G.N. Variation of plant p,p'-DDT uptake with age and soil type and dependence of dissipation on temperature. J. Environ. Int. 1999, 25, 479-487. [CrossRef]

125. Kihampa, C.; Mato, R.R.; Mohamed, H. Residues of organochlorinated pesticides in soil from tomato fields, Ngarenanyuki, Tanzania. J. Appl. Sci. Environ. Manag. 2010, 14, 37-40. [CrossRef]

126. Kishimba, M.A.; Mihale, M.J. Levels of pesticide residues and metabolites in soil at Vikuge Farm, Kibaha District, Tanzania-A classic case of soil contamination by obsolete pesticides. Tanzan. J. Sci. 2004, 30, 77-86. [CrossRef]

127. Koc, F.; Yigit, Y.; Das, Y.K.; Gurel, Y.; Yarali, C. Determinati on of aldicarb, propoxur, carbofuran, carbaryl and methiocarb residues in honey by HPLC with post-column derivatization and fl uorescence detecti on aft er elution from a florisil column. J. Food Drug Anal. 2008, 16, 39-45.

128. Kolb, S.; Fermanich, K.; Dornbush, M. Effect of charcoal quantity on microbial biomass and activity in temperate soils. Soil Sci. Soc. Am. J. 2009, 73, 1173-1181. [CrossRef]

129. Kole, R.K.; Banerjee, H.; Bhattacharyya, A. Monitoring of pesticide residues in farm gate vegetable samples in west Bengal. Pest. Res. J. 2002, 14, 77-82.

130. Kookana, R.S. The role of biochar in modifying the environmental fate, bioavailability, and efficacy of pesticides in soils: A review. Aust. J. Soil Res. 2010, 48, 627-637. [CrossRef]

131. Kostov, D. Atypical grown, abnormal mitosis, polyploidy and chromosome fragmentation induced by hexachlorocyclohexane. Nature 1948, 142, 1111-1116.

132. Krieger, R. Handbook of Pesticide Toxicology: Principles and Agents, 2nd ed.; Academic Press: New York, NY, USA, 2001.

133. Krutz, L.J.; Shaner, D.L.; Accinelli, C.; Zablotowicz, R.M.; Henry, W.H. Atrazine dissipation in s-triazine-adapted and nonadapted soil from Colorado and Mississippi: Implications of enhanced degradation on atrazine fate and transport parameters. J. Environ. Qual. 2008, 37, 848-857. [CrossRef] [PubMed]

134. Kulakow, P.A.; Pidlisnyuk, V.V. NATO Science for Peace and Security Series-C: Environmental Security. In Application of Phytotechnologies for Cleanup of Industrial, Agricultural and Wastewater Contamination; Springer Science + Business Media: Berlin/Heidelberg, Germany, 2010.

135. Laird, B.D.; Goncharov, A.B.; Chan, H.M. Body burden of metals and persistent organic pollutants among Inuit in the Canadian Artic. Environ. Int. 2013, 59, 33-40. [CrossRef] [PubMed]

136. Lasat, M.M. Phytoextraction of metals from contaminated soil: A review of Plant/Metal interaction and assessment of pertinent agronomic issues. J. Hazard. Subs. Res. 2000, 2, 1-25. [CrossRef]

137. Liang, Q.; Lei, M.; Chen, T.; Yang, J.; Wan, X.; Yang, S. Application of sewage sludge and intermittent aeration strategy to the bioremediation of DDT- and HCH-contaminated soil. J. Environ. Sci. 2014, 26, 1673-1680. [CrossRef] [PubMed]

138. Lohmann, R.; Breivik, K.; Dachs, J.; Muire, D. Global fate of POPs: Current and future research directions. Environ. Pollut. 2007, 150, 150-165. [CrossRef]

139. Lunney, A.I.; Zeeb, B.A.; Reimer, K.J. Uptake of weathered DDT invascular plants: Potential for phytoremediation. Environ Sci. Technol. 2004, 38, 6147-6154. [CrossRef] 
140. Lysychenko, G.; Weber, R.; Kovach, V.; Gertsuik, M.; Watson, A.; Krasnova, I. Threats to water resources from hexachlorobenzene waste at Kalush City (Ukraine)-A review of the risks and the remediation options. Environ. Sci. Pollut. Res. Int. 2015, 22, 14391-14404. [CrossRef]

141. Mackay, D.; Shiu, W.Y.; Ma, K.C.; Lee, S.C. Handbook of Physical-Chemical Properties and Environmental Fate of Organic Compounds, 2nd ed.; Taylor and Francis: New York, NY, USA, 2006.

142. Maini, P.; Boni, R. Gas chromatographic determination of dithiocarbamate fungicides in workroom air. Bull. Environ. Contam. Toxicol. 1986, 37, 931-937. [CrossRef]

143. Mamedov, K.; Shamaeva, N.; Rustamova, B. Mutagenic Activity of Pesticides and the Environment; Ylim: Ashgabat, Turkmenistan, 1991; 176p. (In Russian)

144. Manahan, S.E. Fundamentals of Environmental Chemistry, 2nd ed.; CRC Press: Boca Rotan, FL, USA, 2001.

145. Manfo, F.P.T.; Moundipa, P.F.; Dechaud, H.; Tchana, A.N.; Nantia, E.A.; Zabot, M.-T.; Pugeat, M. Effect of agropesticides use on male reproductive function: A study on farmers in Djutitsa (Cameroon). Environ. Toxicol. 2010, 27, 423-432. [CrossRef]

146. Mansour, S.A. Persistent organic pollutants (POPs) in Africa: Egyptian scenario. Hum. Exp. Toxicol. 2009, 28, 531-566. [CrossRef]

147. Marmiroli, N.; Marmiroli, M.; Maestri, E. Phytoremediation and Phytotechnologies: A Review for the Present and the Future. In Soil and Water Pollution Monitoring, Protection and Remediation, Proceedings of the NATO Advanced Workshop, Primosten, Croatia, 9-13 May 2006; Twardowska, I., Allen, H.E., Häggblom, M.H., Stefaniak, S., Eds.; Springer: Dordrecht, The Netherlands, 2006; pp. 403-416.

148. Marmiroli, N.; McCutcheon, S.C. Making Phytoremediation a Successful Technology. In Phytoremediation: Transformation and Control of Contaminants; McCutcheon, S.C., Schnoor, J.L., Eds.; John Wiley \& Sons, Inc.: Hoboken, NJ, USA, 2003; Chapter 3; pp. 85-119.

149. Matthews, G.A. Misery in the Rain Forest. Int. Pest Control 2005, 47, 140-141.

150. Mattina, M.J.I.; Iannucci-Berger, W.; Dykas, L. Chlordane uptake and its translocation in food crops. J. Agric. Food Chem. 2000, 48, 1909-1915. [CrossRef] [PubMed]

151. McCutcheon, S.C.; Schnoor, J.L. Chapter 1: Overview of Phytotransformation and Control of Wastes. In Phytoremediation: Transformation and Control of Contaminants; McCutcheon, S.C., Schnoor, J.L., Eds.; John Wiley \& Sons, Inc.: Hoboken, NJ, USA, 2003; pp. 3-58.

152. McGuinness, M.; Dowling, D. Plant-associated bacterial degradation of toxic compounds in soil. Int. J. Environ. Res. Public Health 2009, 6, 2226-2247. [CrossRef] [PubMed]

153. Medvedeva, G.B. The action of insecticide benzenehexochloride on germinating seeds. J. Agrobiol. 1947, 4, 34-39. (In Russian)

154. Meredith, M.L.; Hites, R.A. Polychlorinated biphenyl accumulation in tree bark and wood growth rings. J. Environ. Sci. Technol. 1987, 21, 709-712. [CrossRef]

155. Mitra, J.; Raghu, K. Effects of DDT on the growth of crop plants. J. Environ. Pol. 1989, 61, 157-170. [CrossRef]

156. Moklyachuk, L.; Drebot, O.; Moklyachuk, O.; Moklyachuk, T.; Monarh, V. Ecological Risks from Contamination of Ukrainian Soils by Persistent Organic Pollutants. Environ. Ecol. Res. 2014, 2, 27-34.

157. Moklyachuk, L.; Gorodiska, I.; Slobodenyuk, O.; Petryshyna, V. Phytoremediation of Soil Polluted with Obsolete Pesticides in Ukraine. In Application of Phytotechnologies for Cleanup of Industrial, Agricultural, and Wastewater Contamination; Kulakow, P.A., Pidlisnyuk, V.V., Eds.; Springer Science + Business Media: Berlin/Heidelberg, Germany, 2010; pp. 113-124.

158. Moorman, T.B.; Cowan, J.K.; Arthur, E.L.; Coats, J.R. Organic amendments to enhance herbicide biodegradation in contaminated soils. Biol. Fertil. Soils 2001, 33, 541-545. [CrossRef]

159. Moosavi, S.G.; Seghatoleslami, M.J. Phytoremediation: A review. Adv. Agric. Biol. 2013, 1, 5-11.

160. Morikawa, H.; Erkin, O.C. Basic principles in phytoremediation and some application to air pollution control. Chemosphere 2003, 52, 1553-1558. [CrossRef]

161. Mrema, E.J.; Rubino, F.M.; Colosio, C. Chapter 1: Obsolete Pesticides-A Threat to Environment, Biodiversity and Human Health. In Environmental Security Assessment and Management of Obsolete Pesticides in Southeast Europe; Simeonov, L.I., Macaev, F.Z., Simeonova, B.G., Eds.; NATO Science for Peace and Security Series C: Environmental Security; Springer Science + Business Media: Dordrecht, The Netherlands, 2013; pp. 1-21.

162. Chen, Z.; Huang, L.; Song, S.; Zhang, Y.; Li, Y.; Tan, H.; Li, X. Enhanced disappearance of mesotrione and fomesafen by water hyacinth in water. Int. J. Phytoremed. 2019, 21, 583-589. [CrossRef] [PubMed] 
163. Murtaza, G.; Murtaza, B.; Niazi, N.K.; Sabir, M. Soil Contaminants: Sources, Effects, and Approaches for Remediation. In Improvement of Crops in the Era of Climatic Changes Volume 2; Ahmad, P., Wani, M.R., Azooz, M.M., Tran, L.-S.P., Eds.; Springer Science + Business Media: New York, NY, USA, 2014; pp. 171-197.

164. Mwegoha, W.J.S. The use of phytoremediation technology for abatement soil and groundwater pollution in Tanzania: Opportunities and challenges. J. Sustain. Dev. Afr. 2008, 10, 140-156.

165. Mwegoha, W.; Mbuya, O.S.; Ugochukwu, N.H.; Abazinge, M. Use of chicken manure for biostimulation and enhancement for perchlorate rhizodegradation in soil and water media. Bioremed. J. 2007, 11, 61-70. [CrossRef]

166. Namgay, T.; Singh, B.; Singh, B.P. Influence of biochar application to soil on the availability of As, Cd, Cu, Pb, and Zn to maize (Zea mays L.). Aust. J. Soil Res. 2010, 48, 638-647. [CrossRef]

167. Nhan, D.D.; Carvalho, F.P.; Am, N.M.; Tuan, N.Q.; Yen, N.T.; Villeneuve, J.P.; Cattini, C. Chlorinated pesticides and PCBs in sediments and molluscs from freshwater canals in the Hanoi region. Environ. Pollut. 2001, 112, 311-320. [CrossRef]

168. Nollet, L.M.L.; Rathore, H.S. Handbook of Pesticides: Methods of Pesticide Residue Analysis; CRC Press: Boca Raton, FL, USA, 2009.

169. Nurzhanova, A.; Kalugin, S.; Zhambakin, K. Obsolete Pesticides and Application of Colonizing Plant Species for Remediation of Contaminated Soil in Kazakhstan. In Proceedings of the 11th Forum of the International $\mathrm{HCH}$ and Pesticide Association. Environ. Sci. Pollut. Res. 2013, 20, 2054-2063. [CrossRef]

170. Nurzhanova, A.; Kulakow, P.A.; Rubin, E.; Rakhimbayev, I.; Sedlovshik, A.; Zhambakin, K.; Kalugin, S.; Kolysheva, E.; Erickson, L.E. Obsolete Pesticide Pollution and Phytoremediation of Contaminated Soil in Kazakhstan. In Application of Phytotechnologies for Cleanup of Industrial, Agricultural, and Wastewater Contamination; Kulakow, P.A., Pidlisnyuk, V.V., Eds.; Springer: Dordrecht, The Netherlands, 2009; pp. 87-112.

171. Nurzhanova, A.; Pidlisnyuk, V.; Kalugin, S.; Stefanovska, T.; Drimal, M. Miscanthus $\times$ giganteus as a new highly efficient phytoremediation agent for improving soils contaminated by pesticide residues and supplemented contaminants. Commun. Appl. Biol. Sci. 2015, 80, 361-366.

172. Nurzhanova, A.; Pidlisnyuk, V.; Sailaukhanuly, Y.; Kenessov, B.; Trogl, J.; Aligulova, R.; Kalugin, S.; Nurmagambetova, A.; Abit, K.; Stefanovska, T.; et al. Phytoremediation of military soil contaminated by metals and organochlorine pesticides using miscanthus. Commun. Agric. Appl. Biol. Sci. 2017, 82, 61-68.

173. Nurzhanova, A.; Rakhimbaev, I.; Zhambakin, K.; Sedlovskiy, A. The problem of obsolete pesticides pollution for the Kazakhstan environment and soil remediation by wild plants. Asian Australas. J. Plant Sci. Biotechnol 2010, 4, 98-103.

174. Nurzhanova, A.; Zhambakin, K.; Rarkhimbayev, I.; Sedlovskiy, A.; Kalugin, S. Obsolete pesicides and phytoremediation of polluted soil in Kazakhstan. J. Life Sci. 2011, 5, 524-535.

175. Nwoko, C.O. Trends in phytoremediation of toxic elemental and organic pollutants. Afr. J. Biotechnol. 2010, 9, 6010-6016.

176. Nzengung, V.A.; Jeffers, P. Sequestration, Phytoreduction, and Phytooxidation of Halogenated Organic Chemicals by Aquatic and Terrestrial Plants. Int. J. Phytorem. 2001, 3, 13-40. [CrossRef]

177. OECD-FAO-UNEP. Report of the OECD-FAO-UNEP Workshop on Obsolete Pesticides Alexandria, Virginia, 13-15 September 2000. Available online: http://www.oecd.org/chemicalsafety/pesticides-biocides/2076941. pdf (accessed on 18 November 2013).

178. Ogbonnaya, U.; Semple, K.T. Impact of biochar on organic contaminants in soil. Agronomy 2013, 3, 349-375. [CrossRef]

179. Ortiz-Hernandez, L.; Sanchez-Salinas, E.; Dantan-Gonzalez, E.; Castrejon-Godinez, M.L. Pesticide Biodegradation: Mecahnisms, Genetics, and Strategies to Enhance the Process. In Biodegradation-Life of Science; Intech: Rijeka, Croatia, 2013; Chapter 10; pp. 251-287.

180. Pascal-Lorber, S.; Laurent, F. Phytoremediation techniques for pesticide contaminations. In Alternative Farming Systems, Biotechnology, Drought Stress and Ecological Fertilization; Lichtfouse, E., Ed.; Springer Science and Business Media: Dordrecht, The Netherlands, 2011; pp. 77-105.

181. Santos, E.; Pires, F.R.; Ferreira, A.D.; Egreja Filho, F.B.; Madalão, J.C.; Bonomo, R.; Rocha Junior, P.R.D. Phytoremediation and natural attenuation of sulfentrazone; mineralogy influence of three highly weathered soils. Int. J. Phytoremed. 2019, 21, 652-662. [CrossRef] [PubMed]

182. Paz-Alberto, A.M.; Sigua, G.C. Phytoremediation: A green technology to remove environmental pollutants. Am. J. Clim. Chang. 2013, 2, 71-86. [CrossRef] 
183. Peltz, C.; Nydick, K.; Fitzgerald, G.; Zillich, C. Biochar for Soil Remediation on Abandoned Mine Lands. In Geological Society of America Abstracts with Programs; Denver Annual Meeting Geological Society of America: Denver, CO, USA, 2010.

184. Pepper, L.A.; Gerba, C.P.; Brusseau, M.L. Pollution Science; Academic Press: San Diego, CA, USA, 1995.

185. Pereira, R.C.; Camps-Arbestain, M.; Garrido, B.R.; Macías, F.; Monterroso, C. Behaviour of alpha-, beta-, gamma-, and delta-hexachlorocyclohexane in the soil-plant system of a contaminated site. Environ. Pollut. 2006, 144, 210-217. [CrossRef]

186. Pham, T.L.; Phan, T.H.; Nguyen, T.D. Analysis of Pesticides in Soil Using Dispersive Solid Phase Extraction Coupled to GC-MS. Soil Sediment Contam. Int. J. 2014, 23, 339-352. [CrossRef]

187. Philippot, L.; Raaijmakers, J.M.; Lemanceau, P.; van der Putten, W.H. Going back to the roots: The microbial ecology of the rhizosphere. Nat. Rev. Microbiol. 2013, 11, 789-799. [CrossRef]

188. Pidlisnyuk, V.; Stefanovska, T. Sustainable agriculture: A New Gender Approach and Challenges for Education. Econ. Environ. Stud. 2004, 6, 311-320.

189. Pidlisnyuk, V.; Stefanovska, T.; Lewis, E.E.; Erickson, L.E.; Davis, C.D. Miscanthus as a Productive Biofuel Crop for Phytoremediation. Crit. Rev. Plant Sci. 2014, 33, 1-19. [CrossRef]

190. Pidlisnyuk, V.; Trogl, J.; Stefanovska, T.; Shapoval, P.; Erickson, L. Preliminary results on growing second generation biofuel crop Miscanthus x giganteus at the polluted military site in Ukraine. Nova Biotechnol. Chim. 2016, 15, 2016. [CrossRef]

191. Pietikäinen, J.; Kiikkilä, O.; Fritze, H. Charcoal as a habitat for microbes and its effect on the microbial community of the underlying humus. Oikos 2000, 89, 231-242. [CrossRef]

192. Pilinskaya, M.A. Evaluation of Mutagenic Potential of Pesticides Taking into Account their Metabolic Transformations. In Modern Issues of Toxicology and Hygiene of the Use of Pesticides and Polymeric Materials; Naukova Dumka: Kiev, Ukraine, 1985; 110p. (In Ukrainian)

193. Pilon-Smits, E.A.H. Phytoremediation. Ann. Rev. Plant Biol. 2005, 56, 15. [CrossRef] [PubMed]

194. Plumer, B. We've covered the world in pesticides. Is that a problem? The Washington Post, 18 August 2013.

195. Prasad, M.N.V.; Freitas, H. Metal hyperaccumulation in plants-Biodiversity prospecting for phytoremediation technology. Electron. J. Biotechnol. 2003, 6, 285-321. [CrossRef]

196. Prasad, K.V.S.K.; Saradhi, P.P.; Sharmila, P. Concerted action of antioxidant enzymes and curtailed growth under zinc toxicity in Brassica juncea. Environ. Exp. Bot. 1999, 42, 1-10. [CrossRef]

197. Prieto-Hontoria, P.L.; Perez-Matute, P.; Fernandez-Galilea, M.; Bustos, M.; Martinez, J.A.; Moreno-Aliaga, M.J. Role of obesity-associated dysfunctional adipose tissue in cancer: A molecular nutrition approach. Biochim. Biophys. Acta 2011, 1807, 664-678. [CrossRef]

198. Purnomo, P.A.S.; Mori, T.; Kamei, I.; Nishii, T.; Kondo, R. Application of mushroom waste medium from Pleurotus ostreatus for bioremediation of DDT-contaminated soil. Int. Biodeterior. Biodegrad. 2010, 64, 397-402. [CrossRef]

199. Raina, V.; Suar, M.; Singh, A.; Prakash, O.; Dadhwal, M.; Gupta, S.K.; Dogra, C.; Lawlor, K.; Lal, S.; van der Meer, J.R.; et al. Enhanced biodegradation of hexachlorocyclohexane ( $\mathrm{HCH})$ in contaminated soils via inoculation with Sphingobium indicum B90A. Biodegradation 2008, 19, 27-40. [CrossRef]

200. Rani, K.; Dhania, G. Review article: Bioremediation and biodegradation of pesticide from contaminated soil and water-A novel approach. Int. J. Curr. Microbiol. Appl. Sci. 2014, 3, $23-33$.

201. Rao, M.A.; Scelza, R.; Scotti, R.; Gianfreda, L. Role of enzymes in the remediation of polluted environments. J. Soil Sci. Plant Nutr. 2010, 10, 333-353. [CrossRef]

202. Rhodes, A.H.; McAllister, L.E.; Chen, R.; Semple, K.T. Impact of activated charcoal on the mineralisation of 14C-phenanthrene in soils. Chemosphere 2010, 79, 463-469. [CrossRef] [PubMed]

203. Rissato, S.R.; Galhiane, M.S.; Apon, B.M.; Arruda, M.S. Multiresidue Analysis of Pesticides in Soil by Supercritical Fluid Extraction/Gas Chromatography with Electron-Capture Detection and Confirmation by Gas Chromatography-Mass Spectrometry. J. Agric. Food Chem. 2005, 53, 62-69. [CrossRef] [PubMed]

204. Rissato, S.R.; Galhiane, M.S.; Fernandes, J.R.; Gerenutti, M.; Gomes, H.M.; Ribeiro, R.; de Almeida, M.V. Evaluation of Ricinus communis L. for the Phytoremediation of Polluted Soil with Organochlorine Pesticides. BioMed Res. Int. 2015, 1, 1-8. [CrossRef] [PubMed] 
205. Roe, R.M.; Hodgson, E.; Rose, R.L.; Thompson, D.M.; Devorshak, C.; Anspaugh, D.D.; Linderman, R.J.; Harris, S.V.; Tomalski, M.D. Basic Principles and Rationale for the Use of Insect Genes in Bioremediation: Esterase Phosphotriesterase Cytochrome P450 and Epoxide Hydrolase. In Pesticides and the Future: Minimizing Chronic Exposure of Humans and the Environment; Kuhr, R.J., Motoyama, N., Eds.; IOS Press: Amsterdam, The Netherlands, 1998; pp. 169-178.

206. Rohrbacher, F.; St Arnaud, M. Root exudation: The ecological driver of hydrocarbon rhizoremediation. Agronomy 2016, 6, 19. [CrossRef]

207. Ruiz, M.J.; Marzin, D. Genotoxicity of six pesticides by Salmonella mutagenicity test and SOS chromotest. J. Mutat. Res. Gen. Toxic. Environ. Mutat. 1997, 390, 245-255. [CrossRef]

208. Rupp, E.B.; Zuman, P.; Sestakova, I.; Horak, V. Polarographic determination of some pesticides. Application to a study of their adsorption on lignin. J. Agric. Food Chem. 1992, 40, 2016-2021. [CrossRef]

209. Rwazo, A. Dumped pesticides persist in Tanzania. Pestic. News 1997, 37, 6-7.

210. Sadowsky, M.J. Phytoremediation: Past Promises and Future Practices. Plant Micro Interact. 2016. Available online: http://socrates.acadiau.ca/isme/Symposium26/SADOWSKYrev.PDF (accessed on 24 November 2016).

211. Saito, T.; Otani, T.; Seike, N.; Murano, H.; Okazaki, M. Suppressive effect of soil application of carbonaceous adsorbents on dieldrin uptake by cucumber fruits. Soil Sci. Plant Nutr. 2011, 57, 157-166. [CrossRef]

212. Sama, D.A. The constraints in managing the pathways of persistent organic pollutants into the large marine ecosystem of the Gulf of Guinea-The case in Cameroon. In Proceedings of the Intergovernmental Forum on Chemical Safety Experts Meeting on Persistent Organic Pollutants, Manila, Philippines, 17-19 June 1996.

213. Sapahin, H.A.; Makahleh, A.; Saad, B. Determination of organophosphorus pesticide residues in vegetables using solid phase micro-extraction coupled with gas chromatography-flame photometric detector. Arabian J. Chem. 2015. [CrossRef]

214. Sasi, K. Phytoremediation: Applications, advantages and Limitations. 2011. Available online: http://www.biotecharticles.com/Applications-Article/Phytoremediation-Applications-Advantagesand-Limitations-785.html (accessed on 24 October 2016).

215. Scoles, M.E. The effect hexachlorocyclohexane on mitosis in root of the onion (Allium cepa) and strawberry (Fragaria vesca). J. Agric. Sci. 1953, 28, 40-45.

216. Semple, K.T.; Reid, B.J.; Fermor, T.R. Impact of composting strategies on the treatment of soils contaminated with organic pollutants. Environ. Pollut. 2001, 112, 269-283. [CrossRef]

217. Semple, K.T.; Riding, M.J.; McAllister, L.E.; Sopena-Vasquuez, F. Impact of carbon on the bioavailability of organic contaminants in soil. J. Hazard. Mater. 2013, 261, 808-816. [CrossRef] [PubMed]

218. Shaker-Koohi, S. Role of arbuscular mycorrhizal (AM) fungi in phytoremediation of soils contaminated: A review. Int. J. Adv. Biol. Biomed. Res. 2014, 2, 1854-1864.

219. Shimabukuro, R.H.; Lamoureux, G.L.; Frear, D.S. Pesticide Metabolism in Plants. In Bioremediation of Pesticides; Matsumura, F., Krishna-Murti, C.R., Eds.; Plenum Press: New York, NY, USA, 1982; pp. 21-66.

220. Singh, N.; Abhilash, P.C. Pesticide use and application: An Indian scenario. J. Hazard. Mater 2009, 165, 1-12.

221. Sinha, R.K.; Valani, D.; Sinha, S.; Singh, S.; Heart, S. Bioremediation of Contaminated sites: A Low-Cost Nature's Biotechnology for Environmental Cleanup by Versatile Microbes, Plants \& Earthworms. In Solid Waste Management and Environmental Remediation; Faerber, T., Herzog, J., Eds.; Nova Science Publishers, Inc.: Hauppauge, NY, USA, 2009; pp. 1-72.

222. Sohi, S.; Krull, E.; Lopez-Capel, E.; Bol, R. A review of biochar and its use and function in soil. Adv. Agron. 2010, 105, 47-82.

223. Spain, J.C.; Hughes, J.B.; Knackmuss, H.J. Biodegradation of Nitroaromatic Compounds and Explosives; Lewis Publishers: Boca Raton, FL, USA, 2000.

224. Spokas, K.A.; Koskinen, W.C.; Baker, J.M.; Reicosky, D.C. Impacts of woodchip biochar additions on greenhouse gas production and sorption/degradation of two herbicides in a Minnesota soil. Chemosphere 2009, 77, 574-581. [CrossRef]

225. Steinbeiss, S.; Gleixner, G.; Antonietti, M. Effect of biochar amendment on soil carbon balance and soil microbial activity. Soil Biol. Biochem. 2009, 41, 1301-1310. [CrossRef]

226. Steiner, C.; Das, K.C.; Garcia, M.; Förster, B.; Zech, W. Charcoal and smoke extract stimulate the soil microbial community in a highly weathered xanthic ferralsol. Pedobiologia 2008, 51, 359-366. [CrossRef]

227. Sutherland, T.; Russel, R.; Selleck, M. Using enzymes to clean pesticide residues. Pestic. Outlook 2002, 13, 149-151. [CrossRef] 
228. Sykes, M.Y.; Vina, B.J.; Abubakr, S. Biotechnology: Working with Nature to Improve Forest Resources and Products. In Proceedings of the International Vetiver Conference, Chiang Rai, Thailand, 4 February 1999; pp. 631-637.

229. Tanga, M.G.; Telefo, P.B.; Tarla, D.N. Alterations in renal functions of market gardeners occupationally exposed to pesticides in West Cameroon. Int. J. Trop. Dis. Health 2016, 20, 1-10. [CrossRef]

230. Tarla, D.N.; Manu, I.N.; Tamedjouong, Z.T.; Kamga, A.; Fontem, D.A. Plight of pesticide applicators in Cameroon: Case of tomato (Lycopersicon esculentum Mill.) farmers in Foumbot. J. Agric. Environ. Sci. 2015, 4, 87-98.

231. Tarla, D.N.; Tchamba, N.M.; Baleguel, N.P.; Baleguel, P.D.; Dobson, H. Inventory of obsolete pesticide stockpiles in Cameroon. Sch. J. Agric. Sci. 2014, 4, 43-50.

232. Tetard-Jones, C.; Edwards, R. Potential roles for microbial endophytes in herbicide tolerance in plants. Pest Manag. Sci. 2016, 72, 203-209. [CrossRef] [PubMed]

233. Tomaszewski, J.E.; Werner, D.; Luthy, R.G. Activated carbon amendment as a treatment for residual DDT in sediment from a superfund site in San Francisco Bay, Richmond, California, USA. Environ. Toxicol. Chem. 2007, 26, 2143-2150. [CrossRef]

234. Tomlin, C.D.S. The Pesticide Manual: A World Compendium; British Crop Production Council: Alton, UK, 2009.

235. Torres, J.P.; Froes-Asmus, C.I.R.; Weber, R.; Vijgen, J.M.H. HCH contamination from former pesticide production in Brazil-A challenege for the Stockholm Convention implementation. Environ. Sci. Pollut. Res. Int. 2013, 20, 1951-1957. [CrossRef]

236. Truu, J.; Truu, M.; Espenberg, M.; Nolvak, H.; Juhanson, J. Phytoremediation and plant assisted bioremediation in soil and treatment wetlands: A review. Open Biotechnol. J. 2015, 9, 85-92. [CrossRef]

237. Uchimiya, M.; Lima, I.M.; Klasson, T.; Wartelle, L.H. Contaminant immobilization and nutrient release by biochar soil amendment: Roles of natural organic matter. Chemosphere 2010, 80, 935-940. [CrossRef]

238. UNEP. The Hazardous Chemicals and Waste Conventions; WHO: Rome, Italy; UNEP: Nairobi, Kenya; FAO: Geneva, Switzerland, 2013; 4p, Available online: http:/www.pops.int/documents/background/hcwc.pdf (accessed on 5 March 2013).

239. UNEP. Riding the World of POPs: A guide on the Stockholm Convention on Persistent Organic Pollutants. 2005. Available online: http://www.pops.int/documents/guidance/beg_guide.pdf (accessed on 20 September 2016).

240. United Chem, LLC. Using QuEChERS Approach for the Determination of Pesticide Residues in Soil. 2014. Available online: http://www.spexsampleprep.com/knowledge-base/resources/application_notes/0714162825-4106-03\%20Pesticides\%20in\%20soil\%20by\%20QuEChERS.pdf (accessed on 7 November 2016).

241. U.S. EPA. Environmental Chemistry Methods; U.S. Environmental Protection Agency: Washington, DC, USA, 2016. Available online: www.epa.gov (accessed on 3 February 2020).

242. U.S. EPA. EPA Methods 8081B, 508.1, 525.2, 508, 505, 625, 527, 507, 8151A; Environmental Applications, Pesticides and Herbicides, Application Note Agilent GC and GC/MS; EPA: Washington, DC, USA, 2012; pp. 429-457.

243. U.S. EPA. An Analysis of composting as an Environmental Remediation Technology; 530-R-98-008; U.S. EPA Report; EPA: Washington, DC, USA, 1998.

244. Van der Lelie, D.; Schwitzguebel, J.P.; Glass, D.J.; Vangronsveld, J.; Baker, A.J.M. Assessing phytoremediation's progress in the United States and Europe. Environ. Sci. Technol. 2001, 35, 446A-452A. [CrossRef]

245. Vijgen, J.; Abhilash, P.C.; Li, Y.-F.; Lal, R.; Forter, M.; Torres, J.; Singh, N.; Yunus, M.; Tian, C.; Schäffer, A.; et al. $\mathrm{HCH}$ as new Stockholm Convention POPs-A global perspective on the management of Lindane and its waste isomers. Environ. Sci. Pollut. Res. Int. 2011, 18, 152-162. [CrossRef]

246. Vijgen, J.; Egenhofer, C. Obsolete (Lethal) Pesticides, a Ticking Time Bomb and Why We Have to Act Now; Tauw Group BV: Deventer, The Netherlands, 2009; 28p, Available online: http://www.ihpa.info/docs/library/ reports/timeBomb_Obsolete_Pesticides.pdf (accessed on 8 January 2012).

247. Wandiga, S.O. Use and distribution of organochlorine pesticides. The future in Africa. Pure Appl. Chem. 2001, 73, 1147-1155. [CrossRef]

248. Wang, F.; Jiang, X.; Bian, Y.R.; Yao, F.X.; Gao, H.J.; Yu, G.F.; Munch, J.C.; Schroll, R. Organochlorine pesticides in soils under different land usage in the Taihu Lake region. China J. Environ. Sci. 2007, 19, 584-590. [CrossRef]

249. Wang, H.L.; Lin, K.D.; Hou, Z.N.; Richardson, B.; Gan, J. Sorption of the herbicide terbuthylazine in two N. Z. forest soils amended with biosolids and biochars. J. Soils Sedim. 2010, 10, 283-289. [CrossRef] 
250. Wang, X.; Zhao, X.; Liu, X.; Li, Y.; Fu, L.; Hu, J.; Huana, C. Homogeneous liquid-liquid extraction combined with gas chromatography-electron capture detector for the determination of three pesticide residues in soils. Anal. Chim. Acta 2008, 620, 162-169. [CrossRef]

251. Wardle, W.A.; Zackrisson, O.; Nilsson, M.C. The charcoal effect in boreal forests: Mechanisms and ecological consequences. Oecologia 1998, 115, 419-426. [CrossRef]

252. Weber, R.; Schlumpf, M.; Nakano, T.; Vijgen, J. The need for better management and control of POPs stockpiles. Environ. Sci. Pollut. Res. 2015, 22, 14385-14390. [CrossRef]

253. White, J.C. Phytoremediation of Weathered p,p'-DDE Residues in Soil. Int. J. Phytorem. 2000, 2, $133-144$. [CrossRef]

254. White, J.C.; Kottler, B.D. Citrate-mediated increase in the uptake of weathered p,p-DDE residues by plants. Environ. Toxicol. Chem. 2002, 21, 550-556. [CrossRef]

255. White, J.C.; Mattina, M.I.; Lee, W.; Eitzer, B.D.; Iannucci-Berger, W. Role of organic acids in enhancing the desorption and uptake of weathered p,p'-DDE by Cucurbita pepo. Environ. Pollut. 2003, 124, 71-80. [CrossRef]

256. White, J.; Zeeb, B. Plant Phylogeny and the Remediation of Persistent Organic Pollutants. In Phytoremediation: Methods in Biotechnology; Humana Press: Totowa, NJ, USA, 2007; pp. 71-87.

257. WHO (World Health Organization). WHO Position Statement on Integrated Vector Management; WHO: Geneva, Switzerland, 2013; 4p, Available online: http://whqlibdoc.who.int/hq/2008/WHO_HTM_NTD_VEM_2008.2_ eng.pdf?ua=1 (accessed on 15 January 2013).

258. WHO. Global Insecticide Use for Vector-Borne Disease Control, 4th ed.; WHO: Geneva, Switzerland, 2009; Available online: http://whqlibdoc.who.int/publications/2009/9789241598781_eng.pdf (accessed on 3 February 2020).

259. Wilkins, C. The uptake of copper, arsenic and zinc by miscanthus-environmental implications for use as an energy crop. Asp. Appl. Biol. 1997, 49, 335-340.

260. Wong, F.; Alegria, H.; Jantunen, L.M.; Bidleman, T.F.; Salvador-Figueroa, M.; Gold-Bouchot, G.; Ceja-Moreno, V.; Waliszewski, S.M.; Infanzón, R. Organochlorine pesticides in soil and air of southern Mexico: Chemical profiles and potential for soil emissions. Atmos. Environ 2008, 42, 7737-7745. [CrossRef]

261. WorldBank Group. Project Assessment Report. Ethiopia, Mali, Morocco, South Africa, Tanzania, Tunisia. Africa Stockpiles Program. 2016. Available online: http://documents.worldbank.org/curated/ en/168841477341223021/pdf/108524-PPAR-PUBLIC.pdf (accessed on 24 November 2016).

262. Writer, S. Nanoparticles and Bioremediation can Decontaminate Polluted Soils. Space Daily, 17 June 2016. Available online: http://go.galegroup.com/ps/i.do?\&id=GALE\T1 \textbar $\{$ A455371910\&v=2.1\&u=ksu\&it= $\mathrm{r} \& \mathrm{p}=\mathrm{ITOF} \& \mathrm{sw}=\mathrm{w} \&$ authCount $=1$ (accessed on 14 January 2017).

263. Xue, N.; Zhang, D.; Xu, X. Organochlorinated Pesticide Multiresidues in Surface Sediments from Beijing, Guanting Reservoir. Water Res. 2006, 40, 183-194. [CrossRef] [PubMed]

264. Yanez-Ocampo, G.; Wong-Villarreal, A.; Del Aguila-Juarez, P.; Lugo-de la Fuente, J.; Vaca-Paulin, R. Composting of soils polluted with pesticides: A microbial approach and methods for monitoring. JSM Environ. Sci. Ecol. 2016, 4, 1032.

265. Yang, Y.; Hunter, W.; Tao, S.; Crowley, D.; Gan, J. Effect of activated carbon on microbial bioavailability of phenanthrene in soils. Environ. Toxicol. Chem. 2009, 28, 2283-2288. [CrossRef]

266. Yu, X.Y.; Ying, G.G.; Kookana, R.S. Reduced plant uptake of pesticides with biochar additions to soil. Chemosphere 2009, 76, 665-671. [CrossRef]

267. Yu, X.Y.; Ying, G.G.; Kookana, R.S. Sorption and desorption behaviors of diuron in soils amended with charcoal. J. Agric. Food Chem. 2006, 54, 8545-8550. [CrossRef]

268. Zhang, H.; Lin, K.; Wang, H.; Gan, J. Effect of Pinus radiata derived biochars on oil sorption and desorption of phenanthrene. Environ. Pollut. 2010, 158, 2821-2825. [CrossRef]

269. Zhang, G.; Chakraborty, P.; Li, J.; Sampathkumar, P.; Balasubramanian, T.; Kathiresan, K.; Takahashi, S.; Subramanian, A.; Tanabe, S.; Jones, K.C. Passive Atmospheric Sampling of Organochlorine Pesticides, Polychlorinated Biphenyls, and Polybrominated Diphenyl Ethers in Urban, Rural, and Wetland Sites along the Coastal Length of India. Environ. Sci. Technol. 2008, 42, 8218-8223. [CrossRef]

270. VandenBerg, H.; Manuweera, G.; Konradsen, F. Global trends in the production and use of DDT for control of malaria and other vector-borne diseases. Malaria J. 2017, 16, 1-8. 
271. Minigh, H. Obsolete and Unwanted Pesticide Stocks: Practical Guidance on Safeguarding, disposal, and Prevention; CropLife International: Brussels, Belgium, 2017.

272. Mulu Loha, K.; Lamoree, M.; Weiss, J.M.; de Boer, J. Import disposal, and health impacts of pesticides in the East Africa Rift (EAR) zone: A review of management and policy analysis. Crop Prot. 2018, 112, 322-331. [CrossRef]

273. Karstensen, K.H.; Kinh, N.K.; Viet, P.H.; Tuan, N.D.; Toi, D.T.; Hung, N.H.; Quan, T.M.; Hanh, L.D.; Thang, D.H. Environmentally sound destruction of obsolete pesticides in developing countries in cement kilns. Environ. Sci. Policy 2006, 9, 577-586. [CrossRef]

274. Singh, A.; Ward, O.P. Applied Bioremediation and Phytoremediation; Singh, A., Ward, O.P., Eds.; Springer: New York, NY, USA, 2004.

275. Baldissarelli, D.P.; Vargas, G.D.L.P.; Korf, E.P.; Galon, L.; Kaufmann, C.; Santos, J.B. Remediation of Soils Contaminated by Pesticides Using Physicochemical Processes: A Brief Review. Planta Daninha 2019, 37, 1-12. [CrossRef]

276. Kearney, P.C.; Roberts, T. Pesticide Remediation in Soils and Water; Kearney, P.C., Roberts, T., Eds.; Wiley: New York, NY, USA, 1998.

277. Cycon, M.; Mrozik, A.; Piotrowska-Seget, Z. Bioaugmentation as a strategy for the remediation of pesticide-polluted soil: A review. Chemosphere 2017, 172, 52-71. [CrossRef] [PubMed]

278. Rodrigo, M.A.; Oturan, N.; Oturan, M.A. Electrochemically assisted remediation of pesticides in soils and water: A review. Chem. Rev. 2014, 114, 8720-8745. [CrossRef]

279. Uqab, B.; Mudasir, S.; Nazir, R. Review on Bioremediation of Pesticides. J. Biorem. Biodegrad. 2016, 7, 1-5.

280. Frazar, C.D. The Bioremediation and Phytoremediation of Pesticide-Contaminated Sites; US Environmental Protection Agency: Washington, DC, USA, 2000. Available online: www.clu-in.org/ (accessed on 3 February 2020).

281. Oturan, N.; Sires, I.; Oturan, M.A.; Brillas, E. Degradation of pesticides in aqueous medium by electro-Fenton and related methods. A review. J. Environ. Eng. Manag. 2009, 19, 235-255.

282. Silva, V.; Mol, H.G.J.; Zomer, P.; Tienstra, M.; Ritsema, C.J.; Geissen, V. Pesticide residues in European agricultural soils: A hidden reality unfolded. Sci. Total Environ. 2019, 653, 1532-1545. [CrossRef]

283. Eevers, N.; White, J.C.; Vongronsveld, J.; Weyens, N. Chapter 7. Bio and phytoremediation of pesticide-contaminated environments: A review. Adv. Bot. Res. 2017, 83, 277-318.

284. Dhankher, O.P.; Doty, S.L.; Meagher, R.B.; Pilon-Smits, E. Biotechnological Approaches for Phytoremediation. In Plant Biotechnology and Agriculture; Altman, A., Hasegawa, P.M., Eds.; Academic Press: New York, NY, USA, 2011; pp. 309-328.

285. Huang, Y.; Xiao, L.; Li, F.; Xiao, D.; Lin, D.; Long, X.; Wu, Z. Microbial degradation of pesticide residues and an emphasis on the degradation of Cypermethrin and 3-phenoxy benzoic acid: A review. Molecules 2018, 23, 2313. [CrossRef]

286. Liu, L.; Bilal, M.; Duan, X.; Iqbal, H.M.N. Mitigation of Environ. Pollut. by genetically engineered bacteria: Current challenges and future prospects. Sci. Total Environ. 2019, 667, 444-454. [CrossRef]

287. Luo, X.; Zhang, D.; Zhou, X.; Du, J.; Zhang, S.; Liu, Y. Cloning and characterization of a pyrethroid pesticide decomposing esterase gene, Est3385, from Rhodopseudomonas palustris PSB-S. Sci. Rep. 2018, 8, 7384. [CrossRef]

288. Behera, K.K. Phytoremediation: Transgenic plants and microbes. Sustain. Agric. Rev. 2014, 13, $65-85$.

289. Pan, X.; Lin, D.; Zheng, Y.; Zhang, Q.; Yin, Y.; Cai, L.; Fang, H.; Yu, Y. Biodegradation of DDT by Stenotroophomonas sp. DDT-1: Characterization and genome functional analysis. Sci. Rep. 2016, 6, 21332. [CrossRef] [PubMed]

290. Singh, S.W.; Bose, P. Degradation of soil-adsorbed DDT and it residues by NZVI addition. RSC Adv. 2015, 5, 94418-94425. [CrossRef]

291. Paschke, A.; Neitzel, P.L.; Walther, W.; Schuurmann, G. Octanol/water partition coefficient for selected herbicides: Determination using shake-flask method and reversed phase high performance liquid chromatography. J. Chem. Eng. Data 2004, 49, 1639-1642. [CrossRef]

292. Toft, P. DDT and Its Derivatives in Drinking Water; WHO/SDE/WSH/03.04/89; World Health Organization: Geneva, Switzerland, 2004; Retrieved December. 
293. Yadav, I.C.; Devi, N.L.; Li, J.; Zhang, G.; Shakya, P.J. Occurrence, profile, and spatial distribution of organochlorine pesticides in soil of Nepal: Implication for source apportionment and health risk assessment. Sci. Total Environ. 2016, 573, 1598-1606. [CrossRef] [PubMed]

294. Zhang, W.J.; Jiang, F.B.; Ou, J.F. Global Pesticide Consumption and Pollution: With China as a Focus. Proc. Acad. Ecol. Environ. Sci. 2011, 1, 125-144.

295. Ipsilantis, I.; Karamesouti, M.; Gasparatos, D. Beneficial Organisms for the Management of Soil Phosphorus. In Sustainable Agriculture Reviews 32; Lichtfouse, E., Ed.; Springer: New York, NY, USA, 2018; pp. 53-75.

296. Pelosi, C.; Barot, S.; Capowiez, Y.; Hedde, M.; Vandenbucke, F. Pesticides and earthworms: A review. Agron. Sustain. Dev. 2014, 34, 199-228. [CrossRef]

297. Arora, S.; Sahni, D. Pesticides effect on soil microbial ecology and enzyme activity-An overview. J. Appl. Nat. Sci. 2016, 8, 1126-1132. [CrossRef]

298. Lo, C.C. Effect of pesticides on soil microbial community. J. Environ. Sci. Health 2010, 45, 348-359. [CrossRef]

299. Zaller, J.G.; Bruhl, C.A. Editorial: Non-target effects of pesticides on organisms inhabiting agroecosystems. Front. Environ. Sci. 2019, 7, 75. [CrossRef]

300. EU. 2009. No. 1107/2009 of the European Parliament and of the Council of 21 October 2009 concerning the placing of plant protection products on the market and repealing Council Directives (EC) No. 79/117 and (EC) No. 91/414. Off. J. Eur. Union 2019, 50, 1-49.

301. Puglisi, E. Response of microbia Zl organisms (aquatic and terrestrial) to pesticides. Supporting Publications. EFSA Support. Publ. 2012, 9, 359E.

302. Romano-Armada, N.; Amoroso, M.J.; Rajal, V.B. Construction of a combined soil quality indicator to assess the effect of glyphosate application. Sci. Total Environ. 2019, 684, 314-325. [CrossRef] [PubMed]

303. Thiour-Mauprivez, C.; Martin-Laurent, F.; Calvayrac, C.; Barthelmebs, L. Effects of herbicide on non-target microorganisms: Towards a new class of biomarkers? Sci. Total Environ. 2019, 684, 314-325. [CrossRef] [PubMed]

304. USEPA. Pesticide Registration: about Pesticide Registration. 2019. Available online: https://www.epa.gov/ pesticide-registration/about-pesticide-registration (accessed on 2 January 2020).

305. Anderson, J.A.; Kruger, E.L.; Coats, J.R. Enhanced degradation of a mixture of three herbicides in the rhizosphere of a herbicide-tolerant plant. Chemosphere 1994, 28, 1551-1557. [CrossRef]

(C) 2020 by the authors. Licensee MDPI, Basel, Switzerland. This article is an open access article distributed under the terms and conditions of the Creative Commons Attribution (CC BY) license (http://creativecommons.org/licenses/by/4.0/). 